\title{
The Record-Breaking Vivian, South Dakota, Hailstorm of 23 July 2010
}

\author{
KATIE L. POJORLIE \\ National Weather Service, Rapid City, South Dakota \\ SCOTT DOERING and MICHAEL A. FOWLE \\ National Weather Service, Aberdeen, South Dakota
}

(Manuscript received 13 October 2011; in final form 29 January 2013)

\begin{abstract}

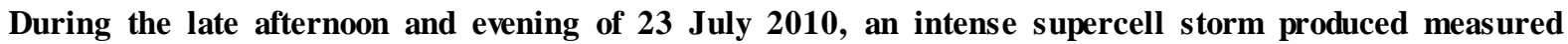
severe wind gusts to $38 \mathrm{~m} \mathrm{~s}^{-1}$ (74 kt), an EF0 tornado, and extremely large hail as it tracked southeastward across south-central South Dakota. Of particular interest was a hailstone that fell in Vivian, South Dakota, that set United States records for maximum weight and diameter. The stone measured $20.32 \mathrm{~cm}(8.00$ in) in diameter, $47.29 \mathrm{~cm}(18.62 \mathrm{in})$ in circumference, and weighed $0.88 \mathrm{~kg}(1.94 \mathrm{lb})$. Because of the historical and record-setting nature of the Vivian hailstone, this event garnered considerable regional and national news media attention.

The objectives of this paper are to review the synoptic and mesoscale environment of this record-setting convective episode. A multi-radar interrogation is also used to depict the extreme radar signatures, even at great distances (> $204 \mathrm{~km}$ or $110 \mathrm{n} \mathrm{mi}$ ) from the nearest WSR-88D radar. The radar signatures from this event are then evaluated relative to the paradigm of known giant $(\geq 10.2 \mathrm{~cm}$ or 4.0 in) hail cases to help provide "calibration" for the operational forecaster when faced with similar extreme storms. Several challenges and best practices associated with verifying and reporting a record hail event also will be discussed.
\end{abstract}

\section{Introduction}

During the late afternoon and evening of 23 July 2010, a mesoscale convective system originating in southwestern North Dakota advanced into northwestern and central South Dakota. As it encountered a warm front and an increasingly moist and unstable air mass, the southern end of this complex intensified into a quasi-linear convective system (QLCS). Around 2100 UTC (4:00 PM CDT), discrete convection started forming to the south of the QLCS (Fig. 1). This convection quickly intensified and evolved into a large, dominant supercell that produced damaging winds up to $38 \mathrm{~m} \mathrm{~s}^{-1}$ (74 kt), an EF0 tornado, and very large hail across portions of south-central South Dakota. It eventually merged with a broken line of thunderstorms to the north and quickly evolved into another QLCS.

A hailstone that fell in Vivian, South Dakota, at approximately 2300 UTC measured $20.32 \mathrm{~cm}$ (8.00 in) in diameter, $47.29 \mathrm{~cm}$ (18.62 in) in circumference, and weighed $0.88 \mathrm{~kg}(1.94 \mathrm{lb})$, setting new United States hail records for maximum diameter and weight. This hailstone (hereafter referred to as the Vivian hailstone) broke the previous diameter record of $17.78 \mathrm{~cm}(7.00$ in) that fell in Aurora, Nebraska, on 22 June 2003 (Guyer and Ewald 2004), and exceeded the previous record for weight of $0.76 \mathrm{~kg}(1.67 \mathrm{lb})$ which occurred in Coffeyville, Kansas, on 3 September 1970. The circumference record for hail is still held by the Aurora hailstone, which was measured at $47.63 \mathrm{~cm}$ (18.75 in; Arndt 2010). This historic and record-breaking Vivian hailstone received significant attention from regional and national news media.

Monfredo (2011) published an overview of the Vivian event, including general information on hail formation as well as a history of record hailstone measurements. While Monfredo does provide a basic overview of several aspects of the Vivian event, this manuscript provides a more in-depth analysis of the following: 1) the mesoscale characteristics including 


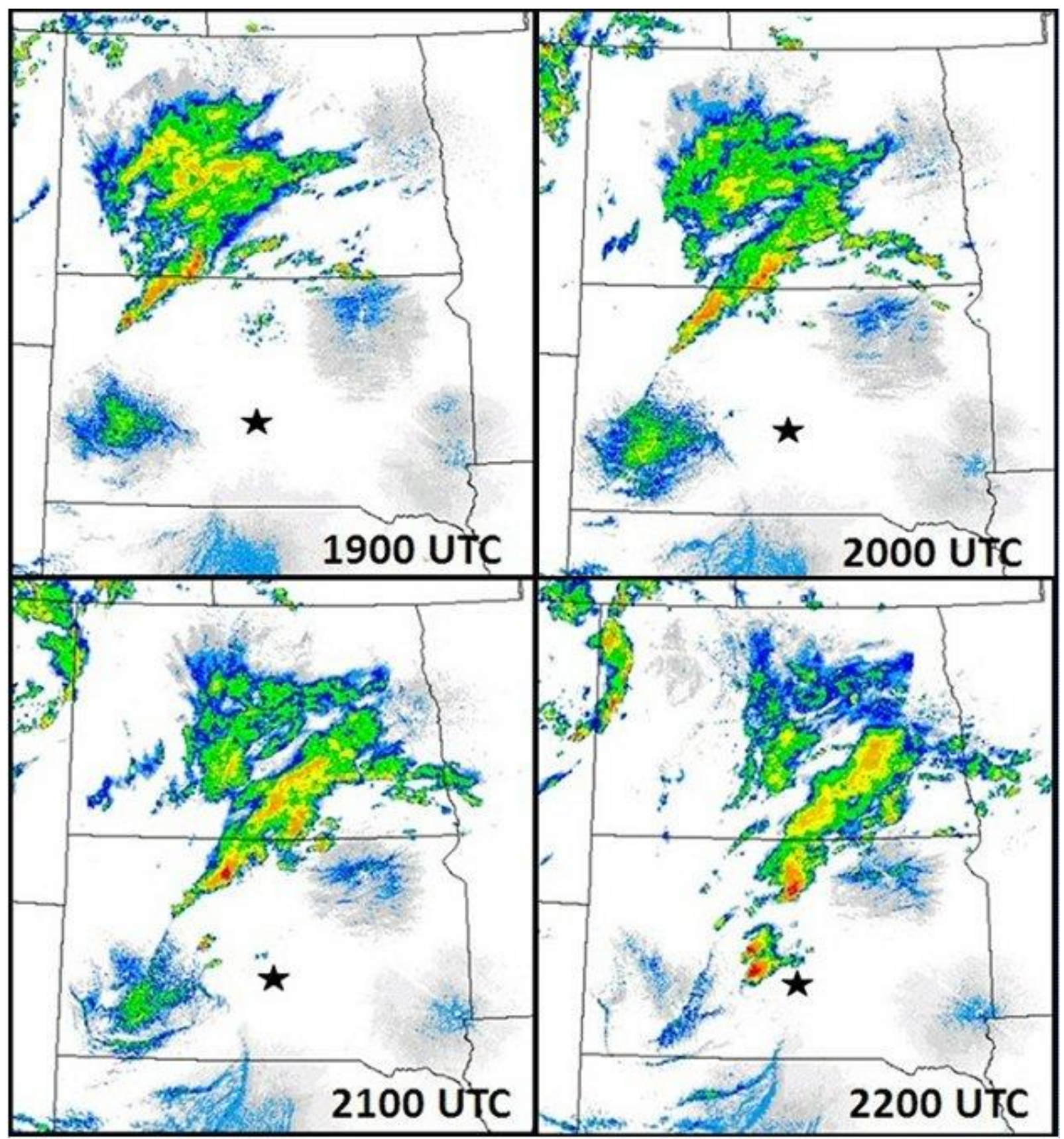

Figure 1. Hourly radar reflectivity mosaic at 1-km above ground level (AGL) from 1900 UTC to 2200 UTC. The black star repres ents the approximate location of Vivian, SD. Images courtesy SPC. Click image for larger version.

thermodynamic and kinematic parameters associated with the event; 2) the near-storm environment of the Vivian hailstorm using model-derived proximity soundings; 3) the storm evolution using multiple National Weather Service (NWS) Weather Surveillance Radar-1988 Doppler (WSR-88D) radars; and 4) the challenges associated with verifying and reporting a record hail event.
The research presented herein will examine several aspects of this record-setting hail event. Sections 2 and 3 provide a synoptic and mesoscale overview of the storm environment; mesoscale data are examined in 3a, while the forecasts created from the mesoscale analyses are evaluated in $3 \mathrm{~b}$. Information regarding the radar data limitations is presented in section $4 \mathrm{a}$, while an analysis of the storm's evolution is given in section $4 b$, along with a comparison to previous events with giant 
hail [i.e., hail $\geq 10.2 \mathrm{~cm}$ (4.00 in), as defined by Knight and Knight (2001)]. Storm survey results are provided in section 5, with concluding remarks in section 6 .

\section{Synoptic overview}

On 23 July 2010 the north-central United States was under a broad trough in the upper and middle troposphere (Figs. $2 \mathrm{a}$ and $2 \mathrm{~b}$, respectively). Additionally, a southwest to northeast-oriented jet streak at $300 \mathrm{hPa}$ was present over South Dakota, with a maximum wind speed of $49 \mathrm{~m} \mathrm{~s}^{-1}$ (95 kt). Southcentral South Dakota was located beneath the right entrance region of the jet streak (Fig. 2a), which implies strong upward motion and has been shown to be a favorable location for severe storms (Clark et al. 2009).

During the late afternoon a surface low deepened gradually to around $1003 \mathrm{hPa}$ over south-central South Dakota. An associated cold front extended westsouthwest from the low pressure system, with a warm front extending to the east-northeast, and a dryline to the south-southwest (Fig. 3). The synoptic environment supported the development of several different mesoscale boundaries that played important roles in the initiation and longevity of the hail-producing supercell, described in greater detail in section 3a.

\section{Mesoscale overview}

\section{a. Data analysis}

As the surface low pressure moved from eastern Wyoming toward central South Dakota on the early morning of 23 July 2010, light and variable surface winds in Nebraska and south-central South Dakota became southerly, resulting in the advection of warm, moist air into the area. At $850 \mathrm{hPa}$, the nose of an 18 to $21 \mathrm{~m} \mathrm{~s}^{-1}$ (35 to $40 \mathrm{kt}$ ) southerly low-level jet stream reached southeastern South Dakota by the late afternoon, and persisted through the evening (Fig. 4). By 2100 UTC, surface temperatures had climbed to the lower $30 \mathrm{~s}{ }^{\circ} \mathrm{C}$ (upper $80 \mathrm{~s}{ }^{\circ} \mathrm{F}$ ), while dew points reached the lower $20 \mathrm{~s}{ }^{\circ} \mathrm{C}$ (lower $70 \mathrm{~s}{ }^{\circ} \mathrm{F}$ ) to the southeast of Vivian (Fig. 3). Moisture was abundant with precipitable water near $4.1 \mathrm{~cm}$ (1.6 in) near Vivian, which is in the $99^{\text {th }}$ percentile for this area in July (Bunkers 2011). These thermodynamic characteristics, along with the boundaries mentioned next, led to an increased potential for deep, moist convection by 2100 UTC.

Boundaries are a favored location for thunderstorm formation and severe weather occurrence (e.g., Maddox

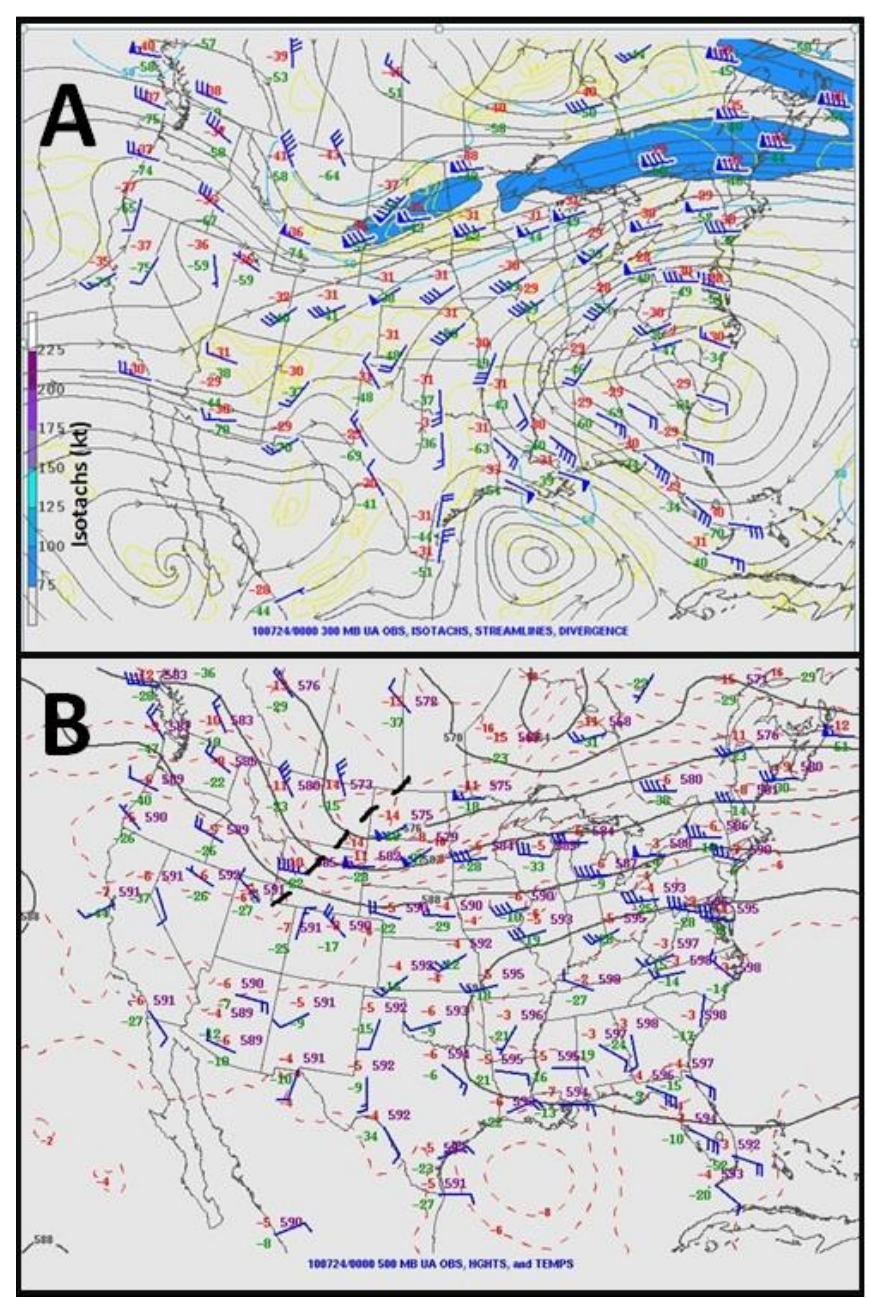

Figure 2. $300-\mathrm{hPa}$ (a) and $500-\mathrm{hPa}$ (b) analyses for 0000 UTC 24 July 2010. Standard station model in abbreviated format; temperature and dew point temperatures $\left({ }^{\circ} \mathrm{C}\right)$ and winds (full barb $=5 \mathrm{~m} \mathrm{~s}^{-1}$, pennant $=25 \mathrm{~m} \mathrm{~s}^{-1}$ ). In panel (a), wind speeds $>38.5 \mathrm{~m} \mathrm{~s}^{-1}$ are shaded in blue, and streamlines are shown in black. In panel (b), temperature (red) is contoured every $2{ }^{\circ} \mathrm{C}$, with geopotential height (black) every $60 \mathrm{~m}$. Images courtesy SPC. Click image for larger version.

et al. 1980; Wilson and Schreiber 1986; Waldstreicher 1989; Markowski et al. 1998). These boundaries, and their associated thermodynamic and kinematic gradients, often contain areas of enhanced moisture, shear, and upward vertical motion. For example, a study on indices of violent tornadoes showed that "the majority of significant tornado reports occurred within the northern gradient... where low-level shear is maximized in the presence of relatively weaker instability (e.g., along a warm front, as opposed to deep within the warm sector)" (Cohen 2010). Furthermore, Smith et al. (2012) indicated that there is considerable overlap between convective modes of storms that 


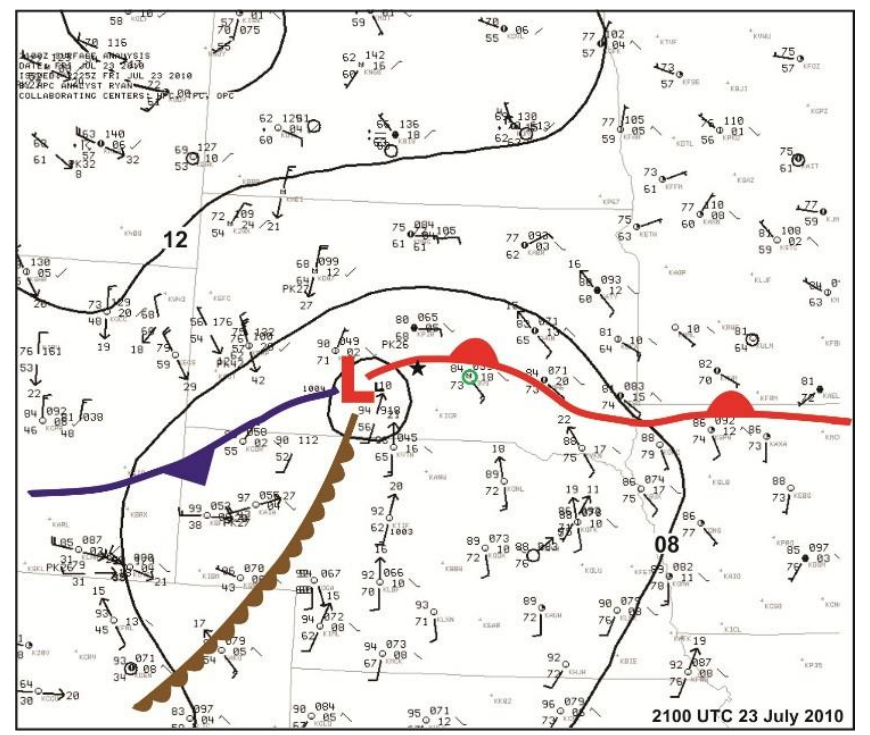

Figure 3. Surface analys is from 2100 UTC on 23 July 2010. Low pressure is shown in south-central South Dakota, with the warm front (red) extending to the east-northeast, the cold front (blue) to the west-southwest, and the dry line (brown) to the south-southwest. Mean sea level pressure (black) contoured every $4 \mathrm{hPa}$ as analyzed by the Hydrometeorological Prediction Center. Standard station model in abbreviated format; temperature and dew point temperatures $\left({ }^{\circ} \mathrm{F}\right.$ ) and winds (full barb $=5 \mathrm{~m} \mathrm{~s}^{-1}$, half barb $=$ $2.5 \mathrm{~m} \mathrm{~s}^{-1}$ ). The black star represents the approximate location of Vivian, SD. The green circle represents Chamberlain, SD (9V9), used in the sounding analysis. Note: the pressure of 991.8 $\mathrm{hPa}$ (918) from the mesonet site in south-central South Dakota was erroneous. Click image for larger version.

produced tornadoes and those that produced significant hail or wind [Hales 1988; hail $\geq 5.08 \mathrm{~cm}$ (2.00 in) or wind $\left.\geq 33.4 \mathrm{~m} \mathrm{~s}^{-1}(65 \mathrm{kt})\right]$; thus, it is reasonable to presume that environments and modes favorable for strong tornadoes are also conducive to generating at least significant hail. While the Vivian supercell produced only one weak tornado, the strongest convection was present just north of the warm front and surface low, which is where convergence and low-level moisture advection were greatest. Tight gradients of convective available potential energy (CAPE) and lowlevel lapse rates also were present along the warm front in southern South Dakota, indicated by an increase of mixed layer CAPE (MLCAPE) from 500 to $4500 \mathrm{~J} \mathrm{~kg}^{-1}$ over a distance of approximately $177 \mathrm{~km}$ (96 n mi; Fig. 5). The warm front also provided a tight delineation of effective bulk shear, with a maximum value of $31 \mathrm{~m} \mathrm{~s}^{-1}$ (60 kt) over Vivian at 2200 UTC (Fig. 6).

Knight and Knight (2001) noted that most hailstone growth occurs between $-10^{\circ}$ and $-30{ }^{\circ} \mathrm{C}$; furthermore,

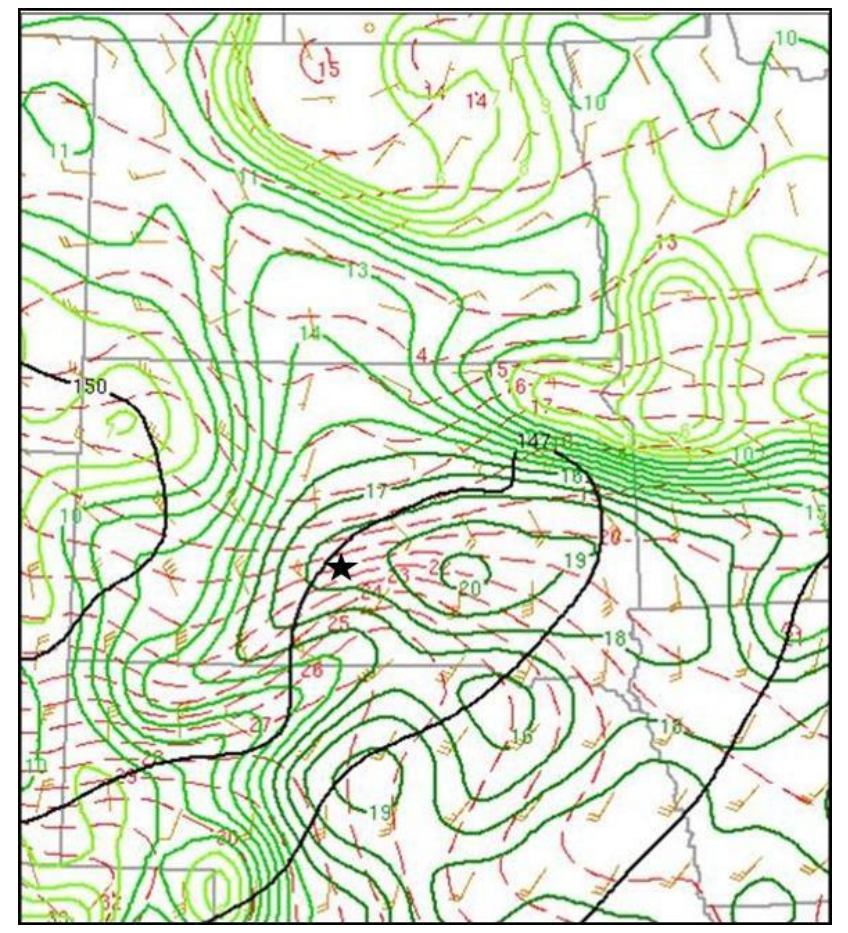

Figure 4. 850-hPa analysis valid at 0000 UTC 24 July 2010. Temperature (red) and dew point temperature (green) are contoured every $1{ }^{\circ} \mathrm{C}$. Wind barbs (brown; full barb $=5$ $\mathrm{m} \mathrm{s}^{-1}$, half barb $=2.5 \mathrm{~m} \mathrm{~s}^{-1}$ ). Geopotential heights (black) are contoured every $30 \mathrm{~m}$. The black star represents the approximate location of Vivian, SD. Image adapted from SPC. Click image for larger version.

large hail formation requires a strong and wide updraft to keep hailstones present long enough in a favorable growth region for substantial mass accumulation (Browning 1977; Foote 1984; Musil et al. 1991). A strong but narrow updraft can result in too small a residence time of hail embryos in the favorable growth region of the updraft (Knight and Knight 2001). CAPE has been "commonly used operationally as an indicator of updraft strength or convective instability" (Edwards and Thompson 1998). Therefore, substantial CAPE within the hail growth zone of $-10^{\circ}$ to $-30{ }^{\circ} \mathrm{C}$, combined with strong wind shear to promote storm organization and updraft ventilation, would suggest that an updraft in this environment would be capable of promoting large hail growth. The most substantial CAPE in the hail growth zone was approximately $1200 \mathrm{~J} \mathrm{~kg}^{-1}$ (Fig. 7); however, there are no known formal references to how this compares to typical values. Nevertheless, the large CAPE and strong shear certainly were favorable for the development of supercells (e.g., Rasmussen and Blanchard 1998), and the rotating updraft of the supercell would further enhance vertical motion 


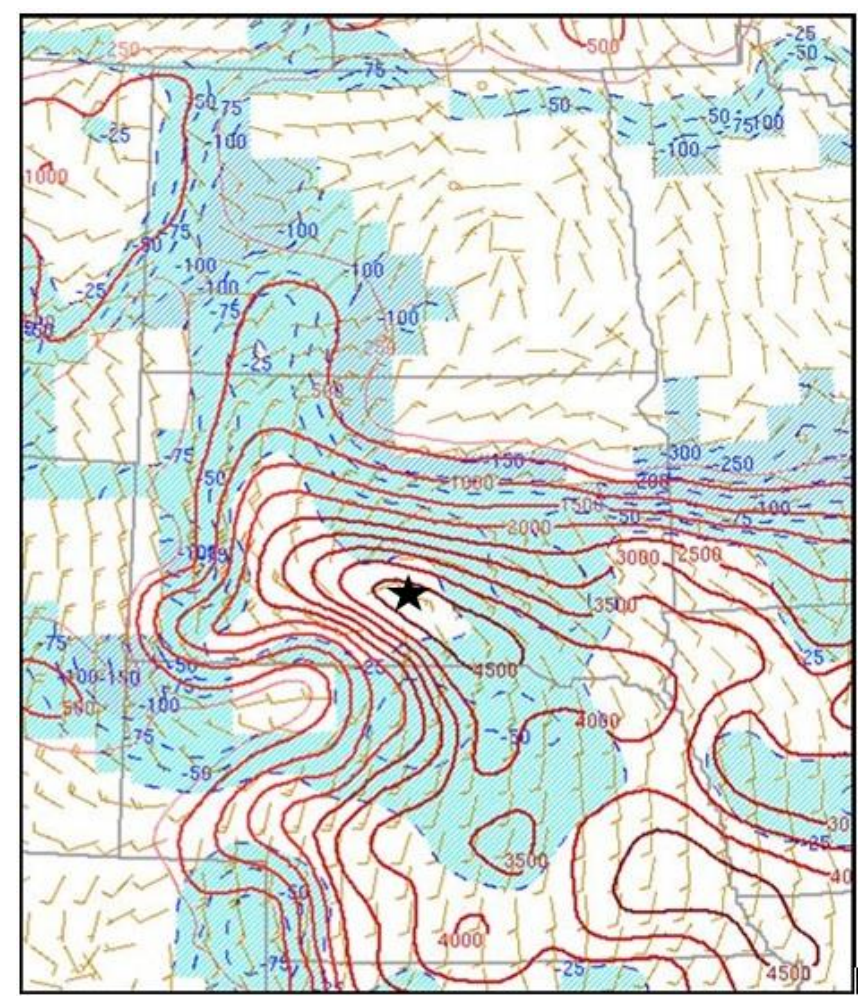

Figure 5. MLCAPE (red) contoured every $500 \mathrm{~J} \mathrm{~kg}^{-1}$ and MLCIN (fill and blue dashed lines, $\mathrm{J} \mathrm{kg}^{-1}$ ) valid for 2200 UTC 23 July 2010. The black star represents the approximate location of Vivian, SD. Image adapted from SPC. Click image for larger version.

through a dynamically induced vertical pressure gradient (Weisman and Klemp 1986).

Neither Aberdeen's nor Rapid City's upper-air sounding is a proximity sounding for Vivian as defined by Rasmussen and Blanchard (1998), and using these soundings would provide little insight into the nearstorm environment for Vivian. To compute several sounding-derived parameters, the 2200 UTC 23 July 2010 Rapid Update Cycle (RUC) model was used. A 2hour forecast sounding, valid for 0000 UTC 24 July 2010 at Chamberlain, South Dakota (Fig. 8), was chosen because of comparable surface conditions between observations and the model in close proximity to Vivian (Fig. 3), and also to avoid contamination of the sounding due to activation of the RUC's convective scheme that began at 2300 UTC and lasted through 0000 UTC. Using a forecast sounding in lieu of an observed sounding is similar to the method used by Thompson et al. (2003).

The RUC sounding showed the highly unstable conditions existing in the Vivian area on 23 July 2010, with $4986 \mathrm{~J} \mathrm{~kg}^{-1}$ of MLCAPE, ML convective inhibition

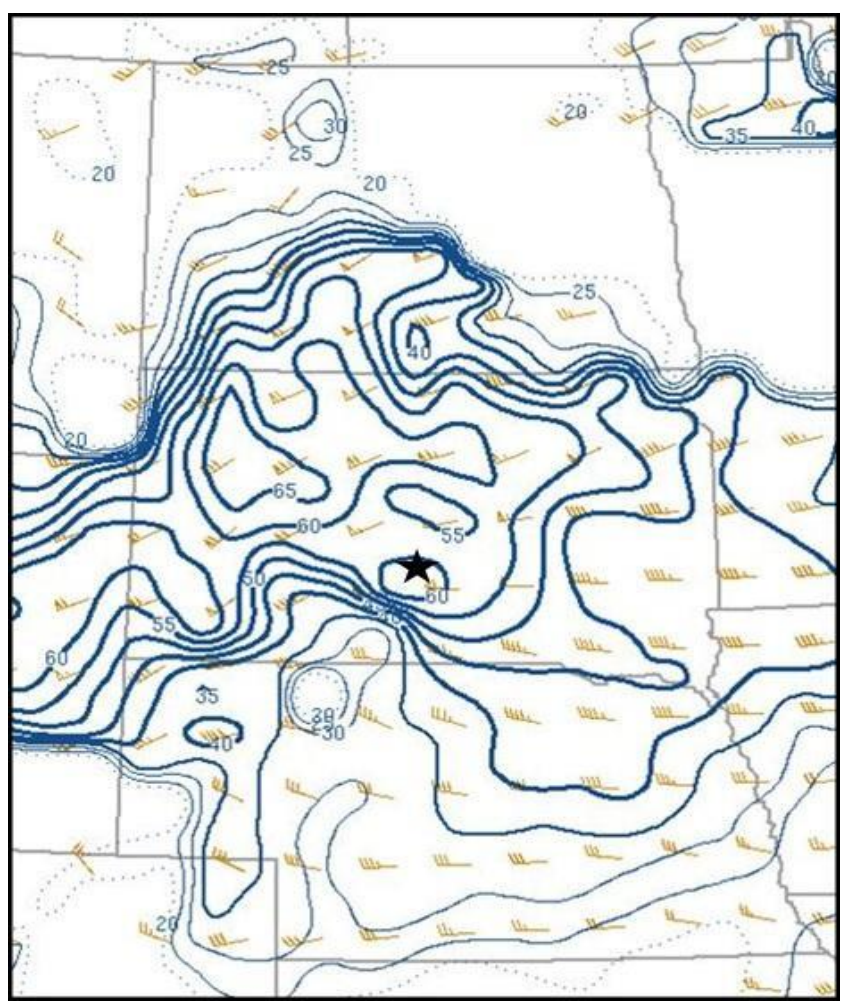

Figure 6. Effective bulk shear (blue) contoured every $2.5 \mathrm{~m}$ $\mathrm{s}^{-1}\left(5 \mathrm{kt}\right.$ ), and also shown as wind barbs (full barb $=5 \mathrm{~m} \mathrm{~s}^{-1}$, pennant $=25 \mathrm{~m} \mathrm{~s}^{-1}$ ) valid for 2200 UTC 23 July 2010. The black star represents the approximate location of Vivian, SD. Image adapted from SPC. Click image for larger version.

(MLCIN) of $61 \mathrm{~J} \mathrm{~kg}^{-1}$, a lifted index (LI) of $-8.9^{\circ} \mathrm{C}$, and a $700-500-\mathrm{hPa}$ lapse rate of $7.8^{\circ} \mathrm{C} \mathrm{km}^{-1}$. High values of deep layer bulk shear (18-26 $\mathrm{m} \mathrm{s}^{-1}$ or 35-50 kt) and 0-3$\mathrm{km}$ storm relative helicity (SRH; 300-400 $\mathrm{m}^{2} \mathrm{~s}^{-2}$ ) are indicative of supercell potential (Rasmussen and Blanchard 1998), increasing the chance of large hail (Miller et al. 1988; Blair et al. 2011). The hodograph (Fig. 8) displays the low-level clockwise curvature that is evident in many severe weather situations (Doswell 1991), with 0-3-km SRH of $390 \mathrm{~m}^{2} \mathrm{~s}^{-2}$ and $0-6-\mathrm{km}$ bulk shear of $21 \mathrm{~m} \mathrm{~s}^{-1}(40 \mathrm{kt})$. The MLCAPE and the $0-3-\mathrm{km}$ SRH were greater than the $90^{\text {th }}$ percentiles of Rasmussen and Blanchard (1998) for storms that produced $>5.07 \mathrm{~cm}(2.0 \mathrm{in})$ diameter hail, and the boundary layer to $6-\mathrm{km}$ shear was near the $75^{\text {th }}$ percentile. The freezing level was $4 \mathrm{~km}(13,100 \mathrm{ft})$ above ground level (AGL), and the wet bulb zero height was at $3.2 \mathrm{~km}(10,500 \mathrm{ft})$ AGL. Although significant melting of hail can occur with these freezing levels (e.g., Johns and Doswell 1992), the height of the freezing level proved insignificant in this case. Donavon and Jungbluth (2007) noted that storms with a 


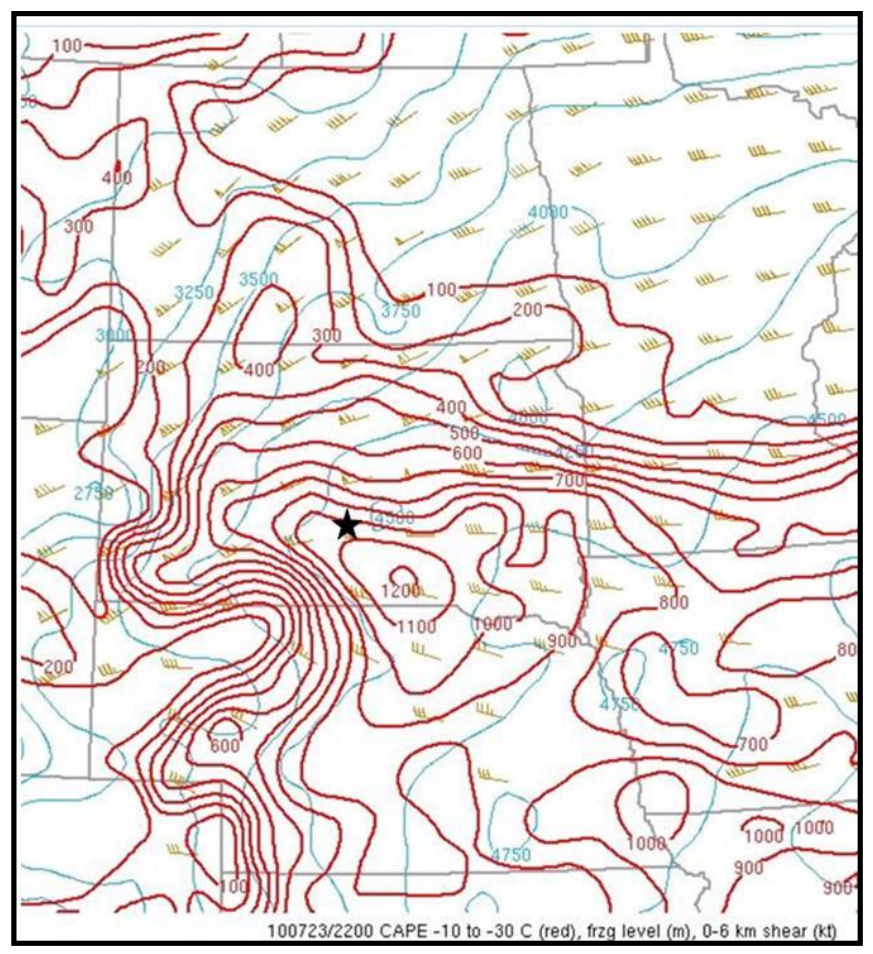

Figure 7. CAPE from -10 to $-30{ }^{\circ} \mathrm{C}$ (red, contoured every $100 \mathrm{~J} \mathrm{~kg}^{-1}$ ), freezing level (blue, contoured every $250 \mathrm{~m}$ ), and $0-6-\mathrm{km}$ shear vectors (full barb $=5 \mathrm{~m} \mathrm{~s}^{-1}$, pennant $=25$ $\mathrm{m} \mathrm{s}^{-1}$ ), valid at 2200 UTC on 23 July 2010. The black star represents the approximate location of Vivian, SD. Image adapted from SPC. Click image for larger version.

"weak echo region (WER)... a three-body scatter spike, or $65+\mathrm{dBZ}$ echo above the [melting level]" can have large hail despite a high freezing level. Furthermore, larger hail has a lower surface area-to-volume ratio than smaller hail, making it melt at a slower rate per unit mass (Rasmussen and Heymsfield 1987). Additionally, larger hail spends less time in the melting layer because of its higher terminal fall velocity (Johns and Doswell 1992).

\section{b. Forecast evaluation}

The Storm Prediction Center (SPC) issued a Day 1 Convective Outlook (Fig. 9) at 0600 UTC (1:00 AM CDT) 23 July 2010. It mentioned the risk of large hail and isolated tornadoes, depicting a 30\% chance of 2.54 $\mathrm{cm}(1.0 \mathrm{in})$ hail within $41 \mathrm{~km}(22 \mathrm{n} \mathrm{mi})$ of a point, with a $10 \%$ chance of this hail being $5.08 \mathrm{~cm}(2.0 \mathrm{in})$ or greater. Subsequent outlooks were similar. SPC also issued a tornado watch later in the day, which was valid from 2045 UTC to 0300 UTC (3:45 PM CDT to 10:00 PM CDT). The watch indicated the threat of $36 \mathrm{~m} \mathrm{~s}^{-1}$ $(70 \mathrm{kt})$ wind gusts and hail to $7.6 \mathrm{~cm}(3.0 \mathrm{in})$ in diameter. The Weather Forecast Office (WFO) in Aberdeen, South Dakota, issued several convective warnings for Lyman County, South Dakota, including the town of Vivian. The initial severe thunderstorm warning issued at 2251 UTC (5:51 PM CDT) forecast hail up to the size of golf balls $(4.45 \mathrm{~cm}$ or $1.75 \mathrm{in})$ and damaging winds in excess of $27 \mathrm{~m} \mathrm{~s}^{-1}(52 \mathrm{kt}$ or $60 \mathrm{mph}$ ). A subsequent update to the initial severe thunderstorm warning [2303 UTC (6:03 PM CDT)] reduced the forecasted hail size to $2.54 \mathrm{~cm}$ (1.0 in). A tornado warning was also issued for the area near Vivian at 2311 UTC (6:11 PM CDT) because of a public report of a tornado touchdown. No mention of hail size was indicated in this tornado warning. The significant under-prediction of hail size in the NWS warnings during the Vivian event is similar to the results found in Blair et al. (2011), and served as further motivation for this study.

\section{Storm evolution and analysis}

\section{a. Radar data limitations}

WSR-88D radar data from Aberdeen (KABR), Rapid City (KUDX), North Platte (KLNX), and Sioux Falls (KFSD) were used to examine this event. One prevailing challenge during the radar analysis was the distance from radars to the Vivian storm (Fig. 10). Rapid City's radar, located in New Underwood, South Dakota, is the closest radar to Vivian at $204 \mathrm{~km}(110 \mathrm{n}$ mi). Vivian is $220 \mathrm{~km}$ (119 n mi) from KLNX, $225 \mathrm{~km}$ (122 $\mathrm{n} \mathrm{mi})$ from KABR, and $288 \mathrm{~km}(156 \mathrm{n} \mathrm{mi})$ from KFSD. It is unfortunate that at its most intense stage, the Vivian supercell was located more than $204 \mathrm{~km}$ (110 $\mathrm{n}$ mi) from all four surrounding radars. This made storm analysis challenging and limited comparisons to the giant hail events in Blair et al. (2011) since their cases were less than $185 \mathrm{~km}(100 \mathrm{n} \mathrm{mi})$ from the closest radar. Nevertheless, this is a situation that occasionally faces operational forecasters.

As radar range increases, beam broadening will result in base-data estimates (e.g., velocity and reflectivity) that are smoothed and often of incorrect intensity due to smearing of the echo in the sample volume (Battan 1973; Blair et al. 2011; Cintineo et al. 2012). Additionally, radar-sampled height is more prone to error at farther distances from the radar. The "height" of features returned by the radar is defined to be the height AGL of the center of the relevant elevation scan radar beam, resulting in uncertainty that is approximately half of the beam diameter (Howard et al. 1997; Maddox et al. 1999; Blair et al. 2011). The radar 


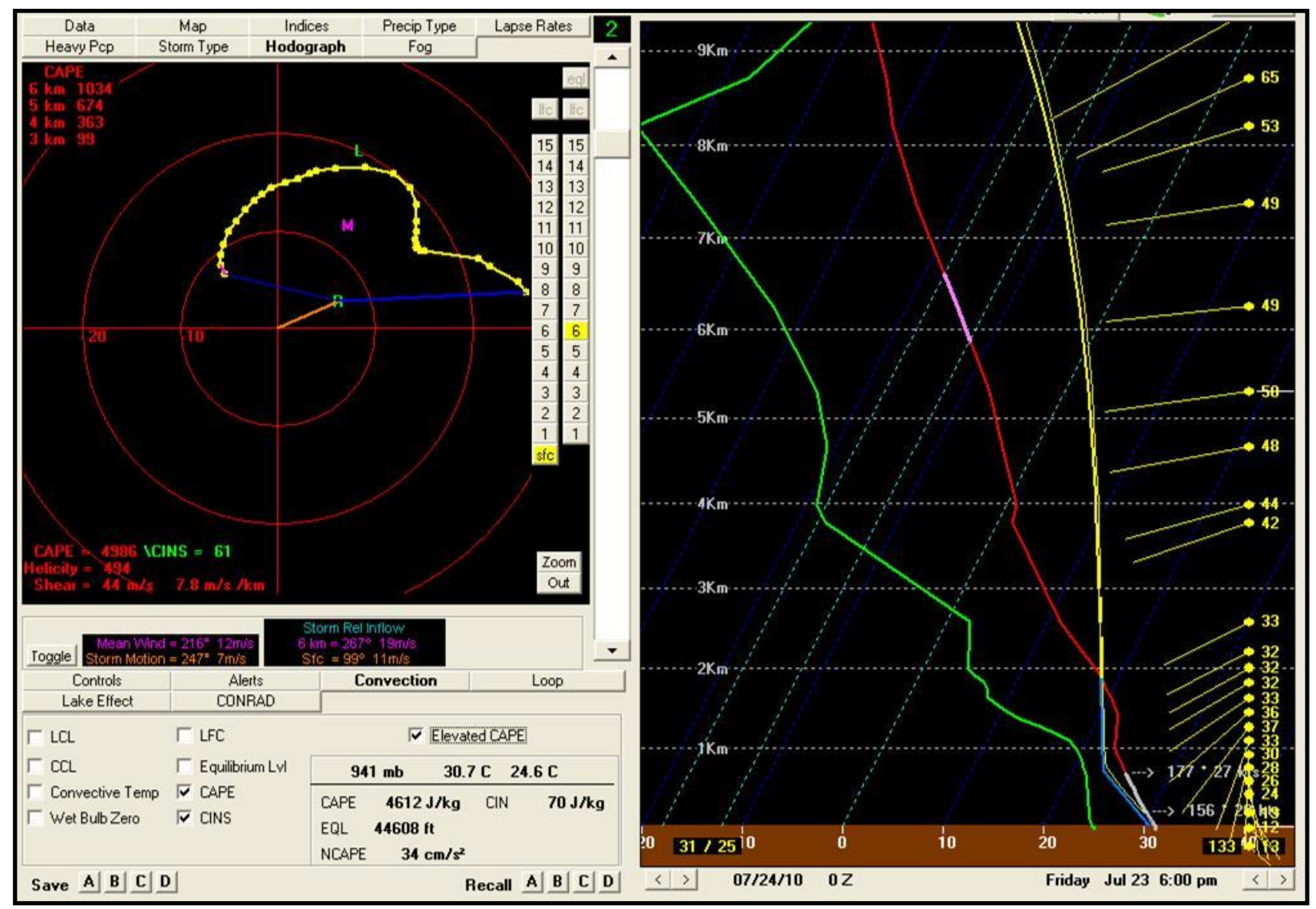

Figure 8. The 2200 UTC 23 July 2010 RUC 2-hour forecast sounding and hodograph valid for 0000 UTC 24 July 2010 at Chamberlain, SD. See Fig. 3 for location of Chamberlain. Click image for larger version.

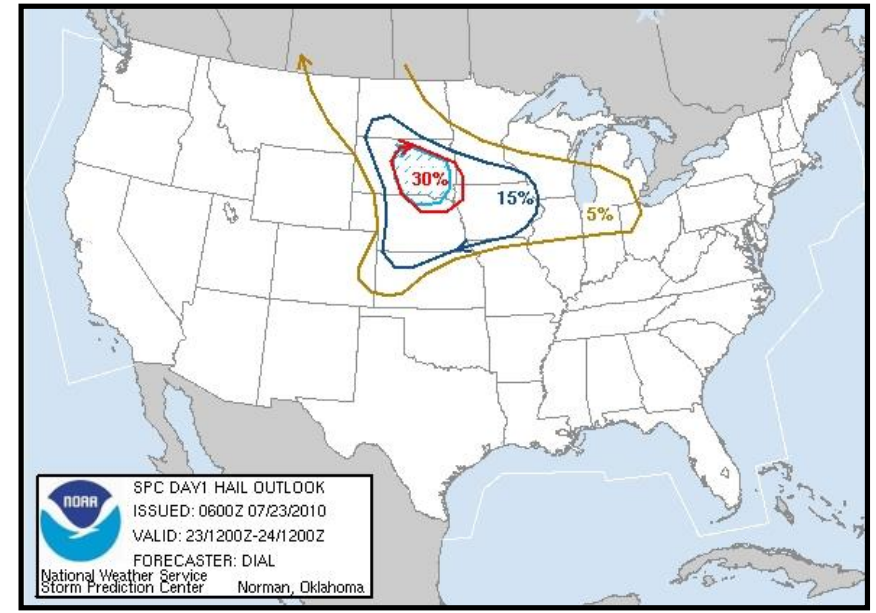

Figure 9. SPC's Day 1 hail outlook issued at 0600 UTC on 23 July 2010, valid from 1200 UTC 23 July 2010 to 1200 UTC 24 July 2010. Depicted is a $30 \%$ chance of $2.54-\mathrm{cm}(1.0-$ in) hail within $41 \mathrm{~km}(22 \mathrm{n} \mathrm{mi})$ of a point for portions of SD, surrounded by $15 \%$ and $5 \%$ chances of $2.54-\mathrm{cm}(1.0$-in) hail within $41 \mathrm{~km}(22 \mathrm{n} \mathrm{mi})$ of a point. The hatched zone indicates where there is at least a $10 \%$ chance of $5.08-\mathrm{cm}(2.0$-in) hail within $41 \mathrm{~km}(22 \mathrm{n} \mathrm{mi})$ of a point. Click image for larger version. beam is also assumed to refract as if propagating through standard atmospheric lapse rates, which is rarely the case. Radar-sampled heights presented from this case are rounded to the nearest $1000 \mathrm{ft}$, which is about $0.3 \mathrm{~km}$, to take this implied imprecision into account. To put these limitations into context, Table 1 shows radar-sampled heights at Vivian for the top, center, and bottom of the beam at the $0.5^{\circ}$ elevation angle for each of the four surrounding radars. Although beam height calculations change with increasing elevation angles, the effective beam width (Table 1) remains constant (WDTB 2012). With KUDX's beam width at Vivian of $3.4 \mathrm{~km}(11,000 \mathrm{ft})$, many storm structures were poorly sampled; furthermore, with KUDX's beam bottom height of $2.7 \mathrm{~km}(9,000 \mathrm{ft})$, the lowest levels of the storm were not sampled at all. Therefore, reports from law enforcement officers and trained spotters were certainly helpful with identifying low-level storm structures. To significantly reduce height uncertainties inherent from a single radar measurement (Maddox et al. 1999), the best available radar data from the nearest four radars were used in the 
storm-scale analysis. In addition, uncertainty can be reduced to a certain extent by averaging the values from the four radars, as shown later in Table 2.

\section{b. Storm evolution}

Discrete thunderstorms initially developed over west-central South Dakota around 2100 UTC 23 July 2010 near a low-level confluent/convergent region of a quasi-stationary surface boundary. The storm first appeared to reach severe intensity [capable of producing $2.54 \mathrm{~cm}$ (1 in) hail, and/or winds of $50 \mathrm{kt}$ (58 $\mathrm{mph})]$ as it tracked across Stanley and Jones Counties (noted in Fig. 11, along with the first severe thunderstorm warning from WFO Aberdeen), with 50$\mathrm{dBZ}$ echoes up to a beam center height of $10.1 \mathrm{~km}$ $(33,000 \mathrm{ft})^{\mathbf{1}}$. At this time, the main core of the storm was still approximately $64 \mathrm{~km}(35 \mathrm{n} \mathrm{mi})$ northwest of Vivian. By $2149 \mathrm{UTC}$, the storm reached $60 \mathrm{dBZ}$ up to heights of $7.0 \mathrm{~km}(23,000 \mathrm{ft})$ AGL or $-20{ }^{\circ} \mathrm{C}\left(-4{ }^{\circ} \mathrm{F}\right)$, suggesting that considerable growth of large hail was occurring (English 1973).

Table 1. Comparison of the radar dimensions from the KABR, KFSD, KLNX, and KUDX radars using the $0.5^{\circ}$ elevation angle, with values found at Vivian, SD. The values displayed are heights AGL, rounded to the nearest $1000 \mathrm{ft}$. Although beam height calculations change with increasing elevation angles, the effective beam width remains constant.

\begin{tabular}{|c|c|c|c|c|}
\hline Radar & $\begin{array}{c}\text { Beam Top } \\
\text { Height }\end{array}$ & $\begin{array}{c}\text { Beam } \\
\text { Center } \\
\text { Height }\end{array}$ & $\begin{array}{c}\text { Beam } \\
\text { Bottom } \\
\text { Height }\end{array}$ & $\begin{array}{c}\text { Effective } \\
\text { Beam } \\
\text { Width }\end{array}$ \\
\hline KABR & $\begin{array}{c}7.0 \mathrm{~km} \\
(23,000 \mathrm{ft})\end{array}$ & $\begin{array}{c}5.2 \mathrm{~km} \\
(17,000 \mathrm{ft})\end{array}$ & $\begin{array}{c}3.4 \mathrm{~km} \\
(11,000 \mathrm{ft})\end{array}$ & $\begin{array}{c}3.7 \mathrm{~km} \\
(12,000 \mathrm{ft})\end{array}$ \\
\hline KFSD & $\begin{array}{c}10.4 \mathrm{~km} \\
(34,000 \mathrm{ft})\end{array}$ & $\begin{array}{c}7.9 \mathrm{~km} \\
(26,000 \mathrm{ft})\end{array}$ & $\begin{array}{c}5.5 \mathrm{~km} \\
(18,000 \mathrm{ft})\end{array}$ & $\begin{array}{c}4.6 \mathrm{~km} \\
(15,000 \mathrm{ft})\end{array}$ \\
\hline KLNX & $\begin{array}{c}7.0 \mathrm{~km} \\
(23,000 \mathrm{ft})\end{array}$ & $\begin{array}{c}5.2 \mathrm{~km} \\
(17,000 \mathrm{ft})\end{array}$ & $\begin{array}{c}3.4 \mathrm{~km} \\
(11,000 \mathrm{ft})\end{array}$ & $\begin{array}{c}3.7 \mathrm{~km} \\
(12,000 \mathrm{ft})\end{array}$ \\
\hline KUDX & $\begin{array}{c}6.1 \mathrm{~km} \\
(20,000 \mathrm{ft})\end{array}$ & $\begin{array}{c}4.6 \mathrm{~km} \\
(15,000 \mathrm{ft})\end{array}$ & $\begin{array}{c}2.7 \mathrm{~km} \\
(9,000 \mathrm{ft})\end{array}$ & $\begin{array}{c}3.4 \mathrm{~km} \\
(11,000 \mathrm{ft})\end{array}$ \\
\hline
\end{tabular}

The thunderstorm continued to intensify and by 2210 UTC was a supercell, as defined by Browning (1977), Weisman and Klemp (1984), and Doswell and Burgess (1993). By 2222 UTC, KUDX indicated a well-defined inflow notch on the $0.5^{\circ}$ and $0.9^{\circ}$ radar elevation angles (Fig. 12), which indicates an area of storm-relative inflow and an updraft, especially with a tight reflectivity gradient (Lemon 1980). Moreover, a bounded weak echo region (BWER) was evident by this

${ }^{1}$ Even though the beam center heights are rounded to the nearest $1000 \mathrm{ft}$, there is greater uncertainty of heights because of the long distances of Vivian from the radars. The effective time on the $1.3^{\circ}$ and $1.8^{\circ}$ elevation angles (Fig. 12). The first report of golf-ball-sized hail occurred $84 \mathrm{~km}$ (45 n mi) northwest of Vivian at 2235 UTC. Ten minutes later, ping-pong-ball-sized hail $(3.81 \mathrm{~cm}$ or $1.5 \mathrm{in})$ damaged siding and broke windows on a farm house 35 $\mathrm{km}(19 \mathrm{n} \mathrm{mi})$ northwest of Vivian, strongly suggesting the hail was accompanied by strong winds. Then at $2248 \mathrm{UTC}$, a $38 \mathrm{~m} \mathrm{~s}^{-1}$ (74 kt) wind gust was reported by the automated mesonet station N0OMP-15, which is 19 $\mathrm{km}(10 \mathrm{n} \mathrm{mi})$ west-northwest of Vivian.

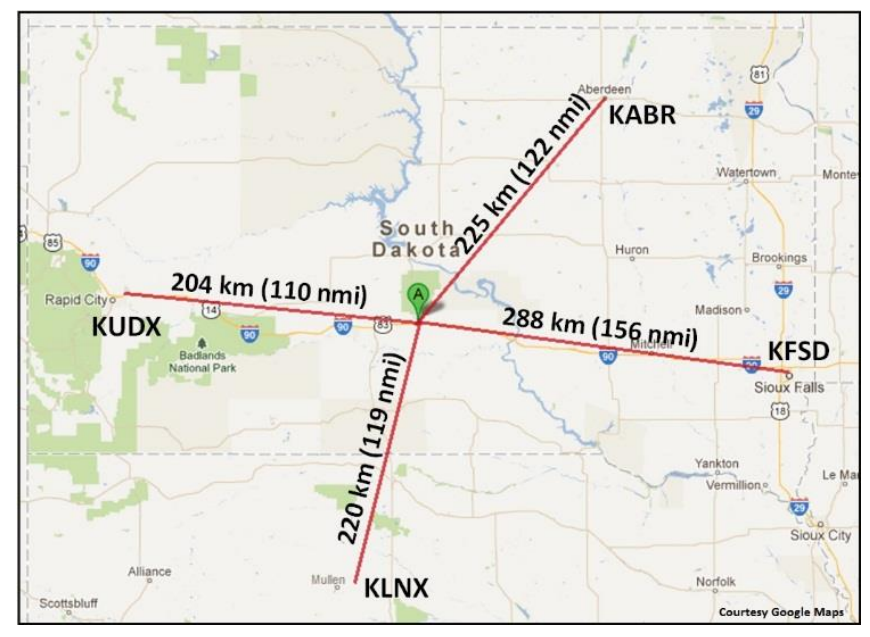

Figure 10. Location of Vivian, SD (point A), and its distance from the surrounding radars, KABR (Aberdeen), KFSD (Sioux Falls), KLNX (North Platte), and KUDX (Rapid City). Image courtesy Google Maps. Click image for larger version.

The Vivian supercell further progressed southeastward along and just to the north of the surface warm front, which may have contributed to the organization and longevity of the supercell (Maddox et al. 1980; Markowski et al. 1998; Atkins et al. 1999). The supercell exhibited a significant increase in midlevel reflectivity around 2254 UTC. At this time, KUDX indicated $65-\mathrm{dBZ}$ echoes at a beam center height of $12.5 \mathrm{~km}(41,000 \mathrm{ft})$ AGL, and a temperature of $-60^{\circ} \mathrm{C}\left(-76^{\circ} \mathrm{F}\right)$, according to the Local Analysis and Prediction System (LAPS; information available online at laps.fsl.noaa.gov/) data. KABR displayed $65 \mathrm{dBZ}$ at a beam center height of $9.8 \mathrm{~km}(32,000 \mathrm{ft}) \mathrm{AGL}$, and LAPS showed a temperature of $-45^{\circ} \mathrm{C}\left(-49^{\circ} \mathrm{F}\right)$. Given the range of beam dimensions (Table 1), the lower bound of the $65-\mathrm{dBZ}$ echo height would be $11.0 \mathrm{~km}$

beam width at Vivian from each radar is $12,000 \mathrm{ft}$ for KABR, $15,000 \mathrm{ft}$ for KFSD, $12,000 \mathrm{ft}$ for KLNX, and 11,000 ft for KUDX (Table 1). 
(36,000 ft) AGL for the closest radar, KUDX. To put this in perspective, a study of giant hail revealed that a $65-\mathrm{dBZ}$ echo up to $10 \mathrm{~km}(32,800 \mathrm{ft})$ AGL ranks at the $75^{\text {th }}$ percentile of the giant-hail-producing storms studied; furthermore, a $65-\mathrm{dBZ}$ echo up to about $11 \mathrm{~km}$ $(36,100 \mathrm{ft})$ AGL ranks at the $90^{\text {th }}$ percentile for giant hail cases (Blair et al. 2011). See below for the limitations of comparison to Blair et al.

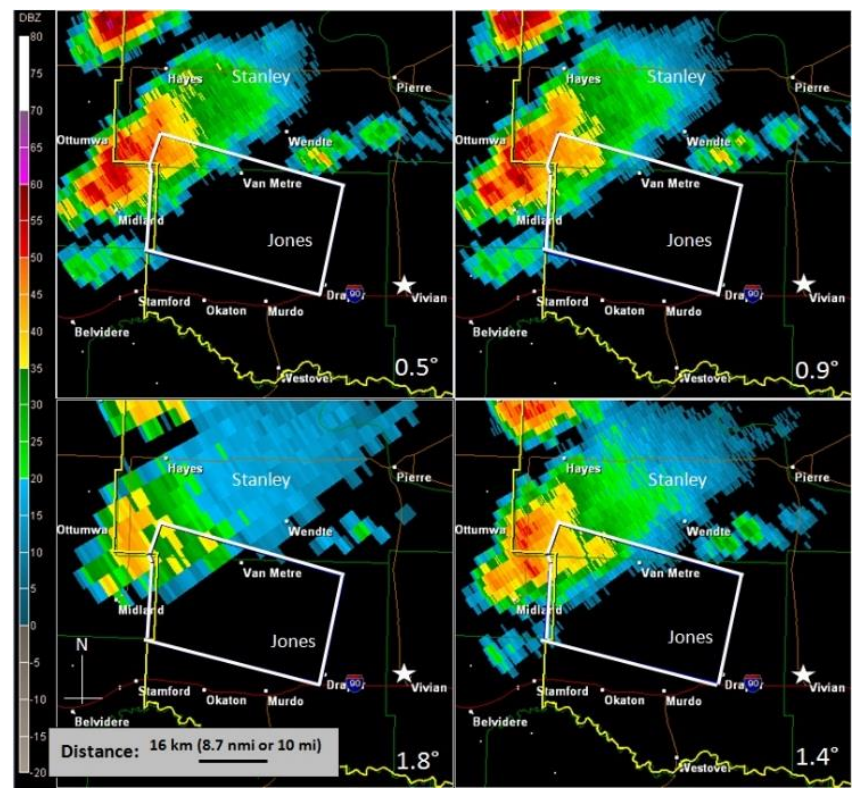

Figure 11. 23 July 2010 reflectivity from KABR at volume time stamp of 2146 UTC. This storm became the Vivian supercell, crossing into WFO Aberdeen's area of responsibility with the first warning (white polygon) issued at 2143 UTC. The range from KABR to the echo top of the storm is $291 \mathrm{~km}(157 \mathrm{n} \mathrm{mi})$. The beam center heights of this point at the $0.5^{\circ}, 0.9^{\circ}, 1.4^{\circ}$, and $1.8^{\circ}$ elevation angles are 5.8 $\mathrm{km}(19,000 \mathrm{ft}), 7.6 \mathrm{~km}(25,000 \mathrm{ft}), 9.4 \mathrm{~km}(31,000 \mathrm{ft})$, and $11.5 \mathrm{~km}(38,000 \mathrm{ft})$, respectively. The white star represents Vivian, SD. Click image for larger version.

At $2258 \mathrm{UTC}$, an intense mesocyclone was evident in KABR's $0.5^{\circ}$ storm-relative velocity data (Fig. 13), at a range of $225 \mathrm{~km}(122 \mathrm{n} \mathrm{mi})$ and beam center height of $5.2 \mathrm{~km}(17,000 \mathrm{ft})$. The maximum rotational velocities $[1 / 2 *$ (|inbound velocity + |outbound velocity|)] were $37 \mathrm{~m} \mathrm{~s}^{-1}$ (71 kt) at this time, decreasing slightly from the storm's lifetime maximum of $38 \mathrm{~m} \mathrm{~s}^{-1}$ $(73 \mathrm{kt})$ at $2254 \mathrm{UTC}$, also from KABR. Peak gate-togate velocity differences likely exceeded $56 \mathrm{~m} \mathrm{~s}^{-1}(110$ $\mathrm{kt})$. Note that environmental flow around the right flank of mesocyclones is often accelerated (e.g., Brown and Torgerson 2005). With the large beam width and depth, there is a good chance that the strong inbound velocity values (Fig. 13) were not purely a result of the flow within the mesocyclone. Conversely, it is noteworthy that these extreme velocities were observed a significant distance from KABR $-225 \mathrm{~km}(122 \mathrm{n} \mathrm{mi})$ away. At this distance, the beam width was $3.7 \mathrm{~km}(2.0$ $\mathrm{n} \mathrm{mi}$ ), and averaging of higher velocity values was undoubtedly occurring. A well-defined BWER was still evident from beam center heights of $4.9 \mathrm{~km}$ to $8.2 \mathrm{~km}$ $(16,000 \mathrm{ft}$ to $27,000 \mathrm{ft}$; Fig. 14), which indicated the persistence of a wide and intense updraft. Additionally, a three-body scatter spike (TBSS) was visible (Fig. 14), which is usually indicative of large hail (Lemon 1998).

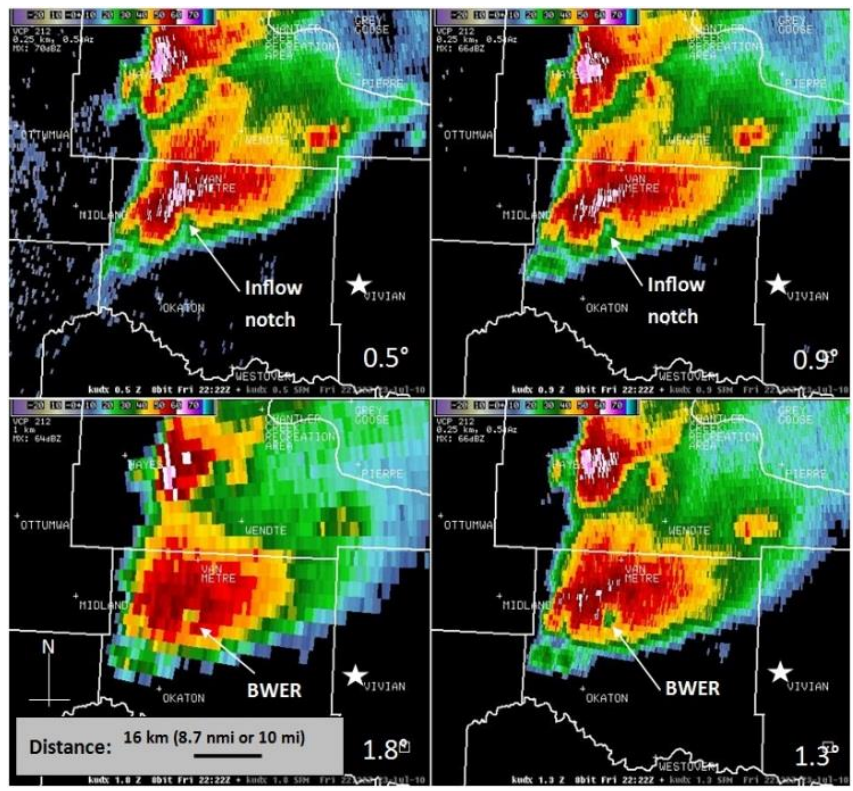

Figure 12. Reflectivity of the Vivian supercell at volume time stamp of 2222 UTC on 23 July 2010 from KUDX. Inflow notch and BWER are indicated. The range of the BWER from KUDX is $185 \mathrm{~km}(100 \mathrm{n} \mathrm{mi})$. The beam center heights of the BWER's location, at the $0.5^{\circ}, 0.9^{\circ}, 1.4^{\circ}$, and $1.8^{\circ}$ elevation angles are $3.4 \mathrm{~km}(11,000 \mathrm{ft}), 4.3 \mathrm{~km}(14,000$ $\mathrm{ft}), 5.5 \mathrm{~km}(18,000 \mathrm{ft})$, and $7.0 \mathrm{~km}(23,000 \mathrm{ft})$, respectively. The white star represents Vivian, SD. Click image for larger version.

The maximum storm-top divergence (STD) was found from KABR at 2302 UTC, and was estimated at $110 \mathrm{~m} \mathrm{~s}^{-1}$ (214 kt; Fig. 15). The values of STD were evaluated by using the Advanced Weather Interactive Processing System (AWIPS). This algorithm produced a more robust dealiased velocity dataset compared to the Gibson Ridge Level II Analyst Edition (GR2AE) velocity dealiasing algorithm, although GR2AE data were acceptable at the lower levels for calculating rotational velocity in Fig. 13. Witt and Nelson (1991) found that an STD of $120 \mathrm{~m} \mathrm{~s}^{-1}(233 \mathrm{kt})$ results in hail

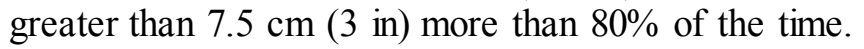




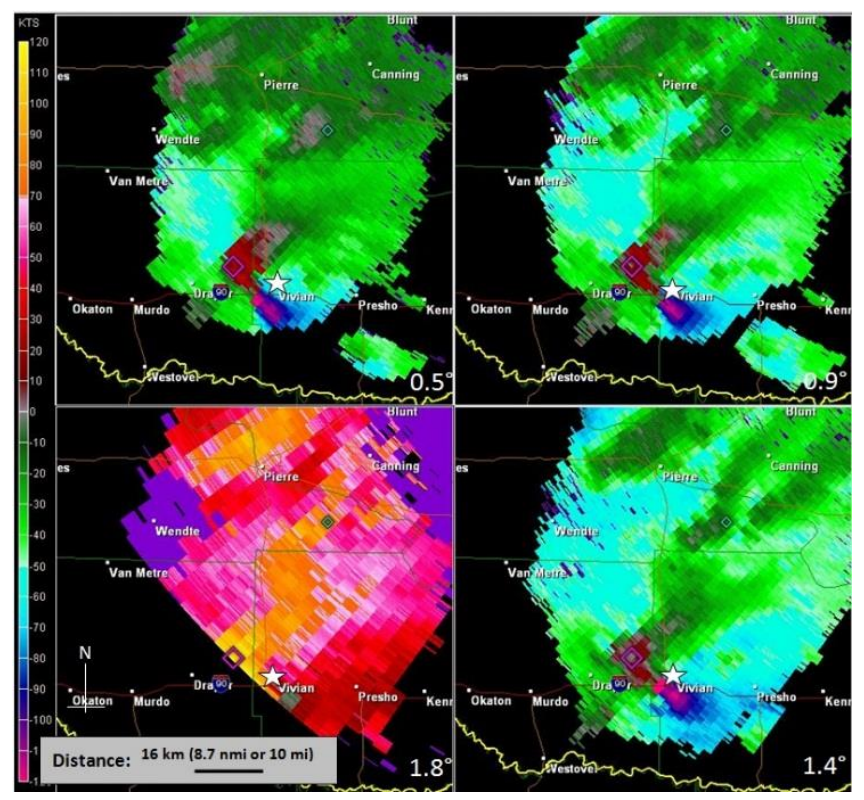

Figure 13. Storm-relative velocity at volume time stamp of $2258 \mathrm{UTC}$ on 23 July 2010 from KABR. Image is from GR2AE. The $1.8^{\circ}$ scan shows a dealiasing error, but the lower scans are similar to what was shown with the algorithm in AWIPS (see text in section $4 b$ ). The range from KABR to the core of the mesocyclone is $263 \mathrm{~km}$ (142 $\mathrm{n} \mathrm{mi).} \mathrm{The} \mathrm{beam}$ center heights of the core's location at the $0.5^{\circ}, 0.9^{\circ}, 1.4^{\circ}$, and $1.8^{\circ}$ elevation angles are $4.9 \mathrm{~km}(16,000 \mathrm{ft}), 6.4 \mathrm{~km}$ $(21,000 \mathrm{ft}), 8.2 \mathrm{~km}(27,000 \mathrm{ft})$, and $10.1 \mathrm{~km}(33,000 \mathrm{ft})$, respectively. The white star represents Vivian, SD. Click image for larger version.

Furthermore, a study by Boustead (2008) showed a high correlation of receiving three-inch diameter hail or greater when the STD is over $118 \mathrm{~m} \mathrm{~s}^{-1}(230 \mathrm{kt})$ with a freezing level greater than $4.4 \mathrm{~km}(14,500 \mathrm{ft})$ AGL. Although the Vivian supercell's STD wasn't quite as high as the STD in these studies, this storm was also a greater distance from the surrounding radars than the storms in those cases.

The Vivian supercell maintained a strong mesocyclone as it crossed the Missouri River around 0000 UTC 24 July 2010. The supercell continued to produce at least golf-ball-sized hail, as well as strong winds in excess of $31 \mathrm{~m} \mathrm{~s}^{-1}(60 \mathrm{kt})$. By $0130 \mathrm{UTC}$, the supercell's mesocyclone weakened and the storm evolved into a line of non-supercellular storms, with strong winds and locally heavy rainfall the primary reports.

Figures 16 through 19 display maximum rotational velocity, STD, 50-dBZ heights, and $60-\mathrm{dBZ}$ heights versus time for the Vivian supercell for the KABR, KUDX, and KLNX radars. The KFSD radar data were not utilized in these graphs because KFSD was in

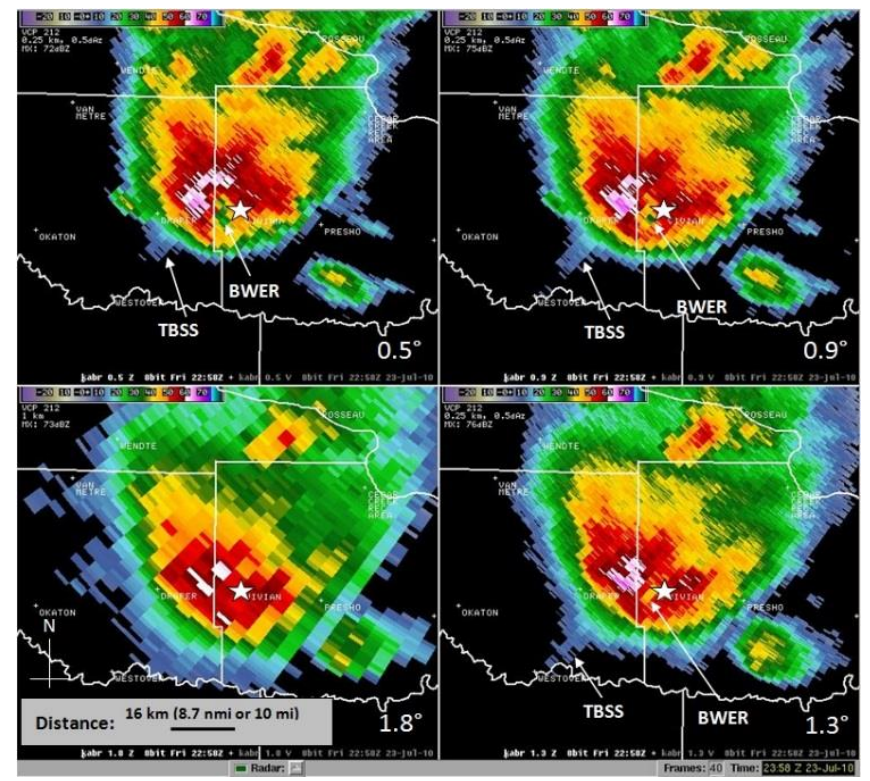

Figure 14. Reflectivity from KABR at volume time stamp of 2258 UTC on 23 July 2010, showing a BWER and threebody scatter spike. The range from KABR to the BWER is $263 \mathrm{~km}$ (142 $\mathrm{n} \mathrm{mi})$. The beam center heights of the BWER's location at the $0.5^{\circ}, 0.9^{\circ}, 1.4^{\circ}$, and $1.8^{\circ}$ elevation angles are $4.9 \mathrm{~km}(16,000 \mathrm{ft}), 6.4 \mathrm{~km}(21,000 \mathrm{ft}), 8.2 \mathrm{~km}(27,000 \mathrm{ft})$, and $10.1 \mathrm{~km}(33,000 \mathrm{ft})$, respectively. The white star represents Vivian, SD. Click image for larger version.

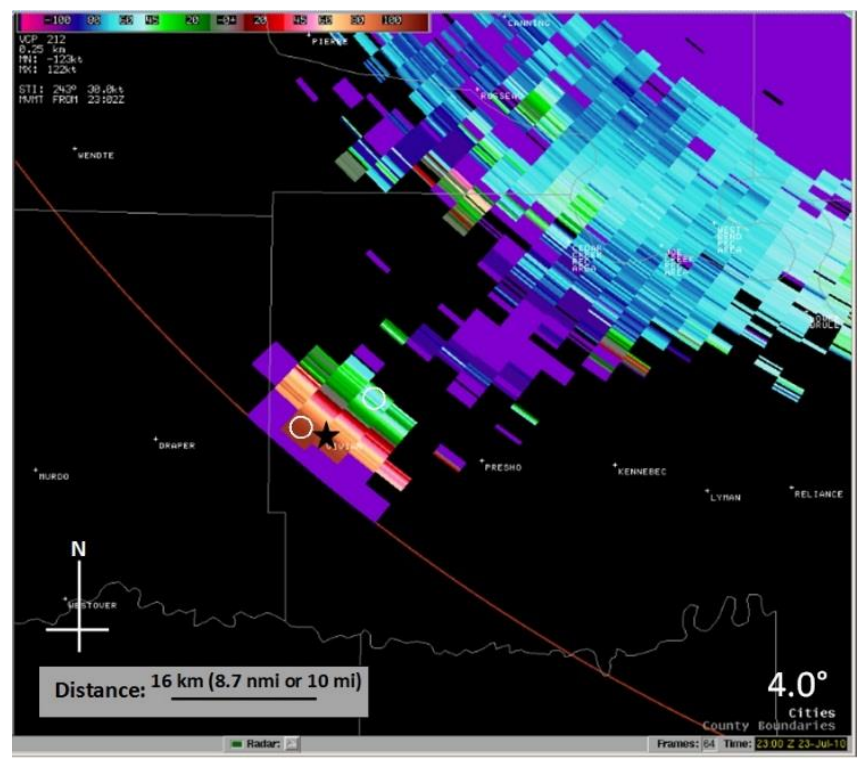

Figure 15. 4.0-degree velocity used to calculate storm-top divergence (STD) from KABR at volume time 2302 UTC on 23 July 2010. The black star represents the location of Vivian, SD. White circles show which values were used in calculating STD. Click image for larger version.

volume coverage pattern 32 (VCP 32; refer to www.wdtb.noaa.gov/courses/dloc/topic $2 /$ rda/vcp.html) 


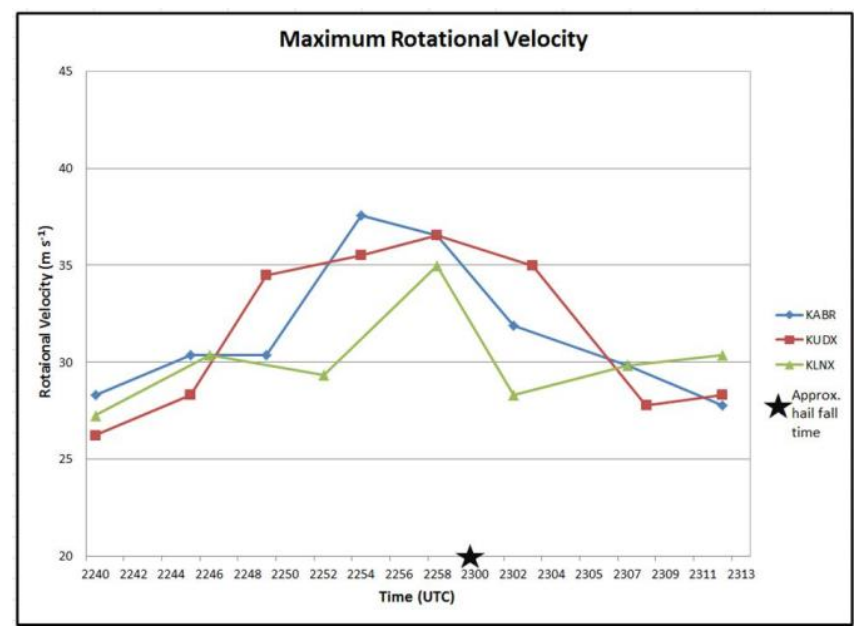

Figure 16. Maximum rotational velocity $\left(\mathrm{m} \mathrm{s}^{-1}\right)$ versus time (UTC) of the Vivian supercell for the KABR, KUDX, and KLNX radars on 23 July 2010. The star represents the approximate time the Vivian hailstone fell. Click image for larger version.

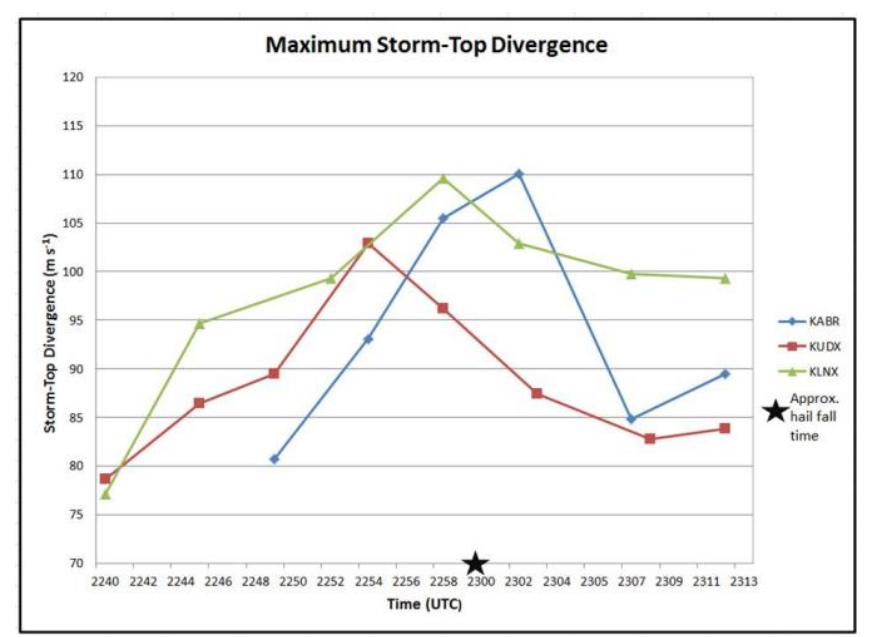

Figure 17. As in Fig. 16 except for storm-top divergence $\left(\mathrm{m} \mathrm{s}^{-1}\right)$. Click image for larger version.

during the time of the supercell's greatest strength, resulting in about half the temporal and spatial coverage relative to the other three radars. KABR and KUDX were in VCP 212, but it should be noted that KLNX was in VCP 21 before switching to VCP 212 at 2258 UTC. Because of how the echoes were sampled from KABR, there was not enough data available to determine STD without using multiple elevation angles during the 2249 UTC through the 2258 UTC scans. Once the storm moved closer to KABR, STD was found using a single elevation angle. Rotational velocity and STD were calculated with methods analogous to Witt and Nelson (1991) and Blair et al. (2011), and methods for finding the maximum 50-dBZ and $60-\mathrm{dBZ}$ heights were similar

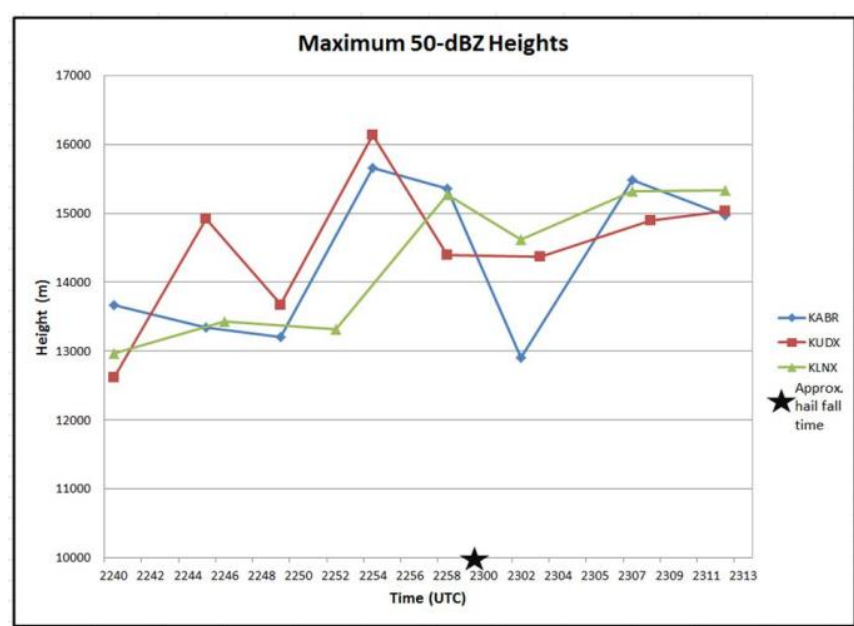

Figure 18. As in Fig. 16 except for maximum height (m) at the beam center point of the $50-\mathrm{dBZ}$ reflectivity values. Click image for larger version.

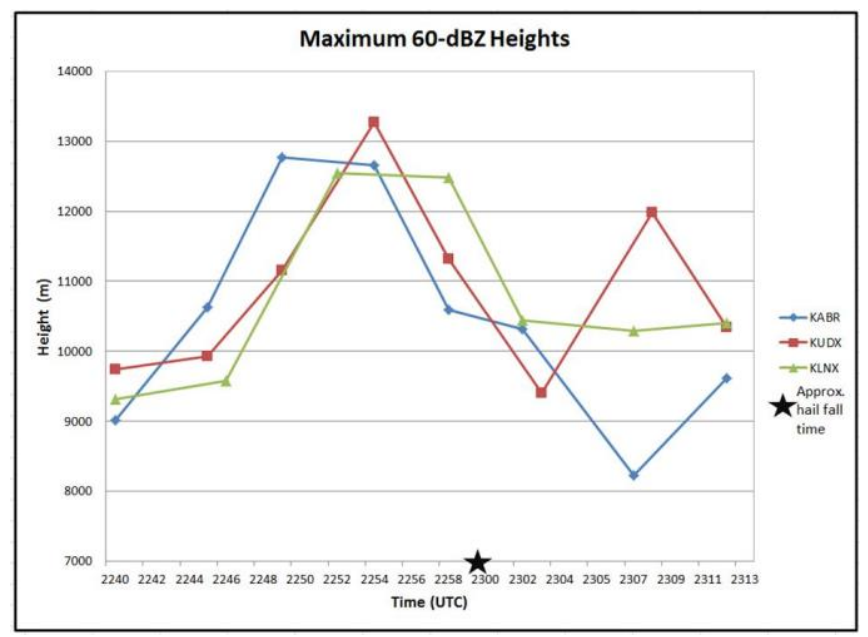

Figure 19. As in Fig. 16 except for maximum height (m) at the beam center point of the $60-\mathrm{dBZ}$ reflectivity values. Click image for larger version.

to those of Donavon and Jungbluth (2007). Peaks of rotational velocity (Fig. 16) and STD (Fig. 17) values are evident in the radar data around or just before 2300 UTC. Immediately after the estimated time the Vivian hailstone fell, the rotational velocity and STD clearly decreased. The maximum 50-dBZ and 60-dBZ heights at the beam center point (Figs. 18 and 19, respectively) show similar trends, although the peaks in values generally occur slightly earlier, and the trends are more irregular than those of rotational velocity and STD.

A study by Blair et al. (2011) presented an analysis of radar signatures and environmental conditions supportive of giant hail events. Included in the assessment were median values of rotational velocity, 


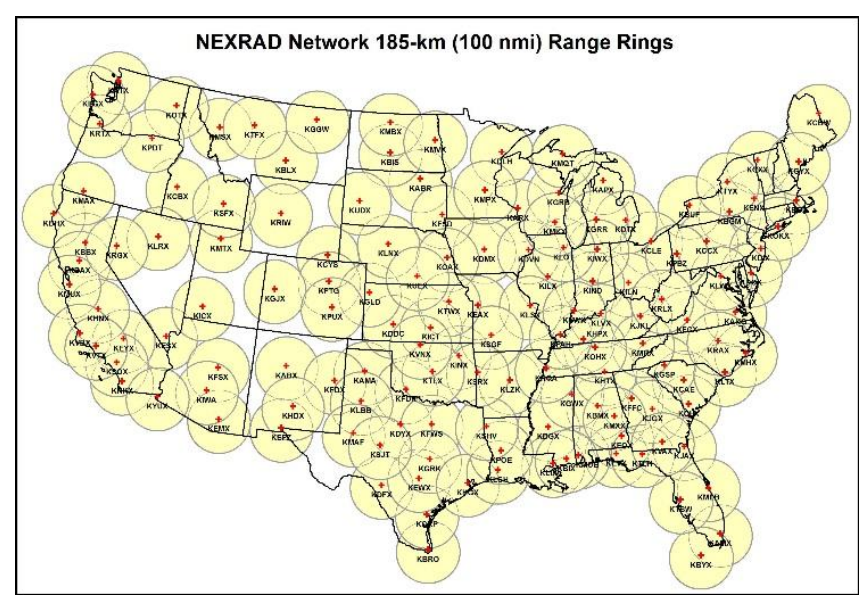

Figure 20. WSR-88D network $185-\mathrm{km}$ (100 n mi) range rings across the continental United States. Click image for larger version.

STD, maximum 50-dBZ height, and maximum $60-\mathrm{dBZ}$ height of storms that produced giant hail, which are important variables that distinguish giant-hailproducing storms from other storms. With the caveats from section $4 \mathrm{a}$ and the ranges from Table 1 in mind, Table 2 presents Blair et al.'s median values along with the values for the Vivian supercell based on the four surrounding radars. Note that the Vivian supercell would not have been included in the Blair et al. giant hail study, because storms farther than $185 \mathrm{~km}(100 \mathrm{n}$ mi) from the radar were excluded. All of the surrounding radars exceeded this distance for the Vivian supercell (Figs. 10 and 20); however, there are several places in the continental U.S. where there is no radar coverage within $185 \mathrm{~km}$ (100 $\mathrm{n} \mathrm{mi}$; Fig. 20). Therefore, examining the impact of radar limitations on storm analysis and comparing these findings to the Blair et al. study potentially can help forecasters in these areas determine if the results can be applied or need to be modified for storms that are large distances from the radar. Any comparisons to Blair et al. given throughout this paper are meant to provide context for evaluation, not to validate or invalidate any of their findings. The values in Table 2 for the Vivian case were from within approximately 15 minutes before and 5 minutes after the record-setting hail fell. Note that the STD was not available for KFSD because of the storm's distance from the radar and the volume coverage pattern. While sufficient data from KFSD were not available for Figs. 16 through 19, maximum values of rotational velocity and the $50-\mathrm{dBZ}$ and $60-\mathrm{dBZ}$ heights are provided for additional reference and comparison.
All four radars shown in Table 2 displayed values associated with the Vivian supercell significantly higher than the medians found in Blair et al. (2011), closer to the $90^{\text {th }}$ percentile, for these four radar-based indicators of giant-hail-producing storms. Moreover, the individual radar values did not deviate substantially from the average (Table 2), which suggests that even at these far ranges the radar provided valuable information. Post analysis indicates that even among giant hail events, the Vivian hailstorm had remarkable radar-based characteristics.

Table 2. Comparison of rotational velocity, storm-top divergence, maximum 50-dBZ height AGL, and maximum 60-dBZ height AGL of the Vivian supercell from the KABR, KFSD, KLNX, and KUDX radars to the median values found for giant hail by Blair et al. (2011). Maximum reflectivity values listed are relative to the beam center height (WDTB 2012), rounded to the nearest $1000 \mathrm{ft}$. Averages were calculated based on the values before rounding. Values for the Vivian supercell were taken approximately 15 minutes before to 5 minutes after 2300 UTC.

\begin{tabular}{|c|c|c|c|c|}
\hline & $\begin{array}{c}\text { Rotational } \\
\text { Velocity }\end{array}$ & $\begin{array}{c}\text { Storm-Top } \\
\text { Divergence }\end{array}$ & $\begin{array}{c}\text { Maximum } \\
\mathbf{5 0 - d B Z} \\
\text { Height }\end{array}$ & $\begin{array}{c}\text { Maximum } \\
\text { 60-dBZ } \\
\text { Height }\end{array}$ \\
\hline $\begin{array}{c}\text { Research } \\
\text { Medians } \\
\text { (Blair et } \\
\text { al. 2011) }\end{array}$ & $\begin{array}{c}24 \mathrm{~m} \mathrm{~s}^{-1} \\
(47 \mathrm{kt})\end{array}$ & $\begin{array}{c}72 \mathrm{~m} \mathrm{~s}^{-1} \\
(140 \mathrm{kt})\end{array}$ & $\begin{array}{c}13.1 \mathrm{~km} \\
(43,000 \mathrm{ft})\end{array}$ & $\begin{array}{c}10.6 \mathrm{~km} \\
(34,800 \mathrm{ft})\end{array}$ \\
\hline KABR & $\begin{array}{c}38 \mathrm{~m} \mathrm{~s}^{-1} \\
\left(73 \mathrm{kt}^{-1}\right.\end{array}$ & $\begin{array}{c}110 \mathrm{~m} \mathrm{~s}^{-1} \\
(214 \mathrm{kt})\end{array}$ & $\begin{array}{c}15.7 \mathrm{~km} \\
(51,000 \mathrm{ft})\end{array}$ & $\begin{array}{c}12.7 \mathrm{~km} \\
(42,000 \mathrm{ft})\end{array}$ \\
\hline KFSD & $\begin{array}{c}35 \mathrm{~m} \mathrm{~s}^{-1} \\
(68 \mathrm{kt})\end{array}$ & $\mathrm{N} / \mathrm{A}$ & $\begin{array}{c}13.9 \mathrm{~km} \\
(46,000 \mathrm{ft})\end{array}$ & $\begin{array}{c}12.5 \mathrm{~km} \\
(41,000 \mathrm{ft})\end{array}$ \\
\hline KLNX & $\begin{array}{c}35 \mathrm{~m} \mathrm{~s}^{-1} \\
(68 \mathrm{kt})\end{array}$ & $\begin{array}{c}110 \mathrm{~m} \mathrm{~s}^{-1} \\
(213 \mathrm{kt})\end{array}$ & $\begin{array}{c}15.2 \mathrm{~km} \\
(50,000 \mathrm{ft})\end{array}$ & $\begin{array}{c}12.5 \mathrm{~km} \\
(41,000 \mathrm{ft})\end{array}$ \\
\hline KUDX & $\begin{array}{c}37 \mathrm{~m} \mathrm{~s}^{-1} \\
(71 \mathrm{kt})\end{array}$ & $\begin{array}{c}103 \mathrm{~m} \mathrm{~s}^{-1} \\
(200 \mathrm{kt})\end{array}$ & $\begin{array}{c}16.2 \mathrm{~km} \\
(53,000 \mathrm{ft})\end{array}$ & $\begin{array}{c}13.4 \mathrm{~km} \\
(44,000 \mathrm{ft})\end{array}$ \\
\hline $\begin{array}{c}\text { Average } \\
\text { from } \\
\text { the radars }\end{array}$ & $\begin{array}{c}36 \mathrm{~m} \mathrm{~s} \mathrm{~s}^{-1} \\
(70 \mathrm{kt})\end{array}$ & $\begin{array}{c}108 \mathrm{~m} \mathrm{~s} \mathrm{~s}^{-1} \\
(209 \mathrm{kt})\end{array}$ & $\begin{array}{c}15.2 \mathrm{~km} \\
(50,000 \mathrm{ft})\end{array}$ & $\begin{array}{c}13.0 \mathrm{~km} \\
(43,000 \mathrm{ft})\end{array}$ \\
\hline
\end{tabular}

\section{Storm survey results}

At 2200 UTC WFO Aberdeen began receiving reports of severe hail and wind. By 2300 UTC, the supercell reached Vivian, where reports of a tornado and giant hail were received. Fifteen or so very large hailstones were collected by several residents. One Vivian resident collected about 10 additional hailstones of softball size $(10.16 \mathrm{~cm}$ or $4.0 \mathrm{in}$; some of which are shown in Fig. 21), including one that had a diameter of what was unofficially estimated as $28 \mathrm{~cm}$ (11.00 in). The resident put the unsealed stones in the freezer, and a storm-related power outage resulted in some melting. On the morning of 24 July 2010 official measurements conducted by WFO Aberdeen staff confirmed the legitimacy of the reported giant-sized hailstones. The 
largest stone preserved - the aforementioned hailstone with the unofficial diameter of $28 \mathrm{~cm}$ (11.00 in) - was found to be $20.32 \mathrm{~cm}(8.00 \mathrm{in})$ in diameter (Fig. 22a) and $47.29 \mathrm{~cm}$ (18.62 in) in circumference (Fig. 22b). On 25 July 2010, the hailstone's weight of $0.88 \mathrm{~kg}(1.94 \mathrm{lb})$ was measured on a certified scale provided by the U.S. Post Office in Vivian, South Dakota.

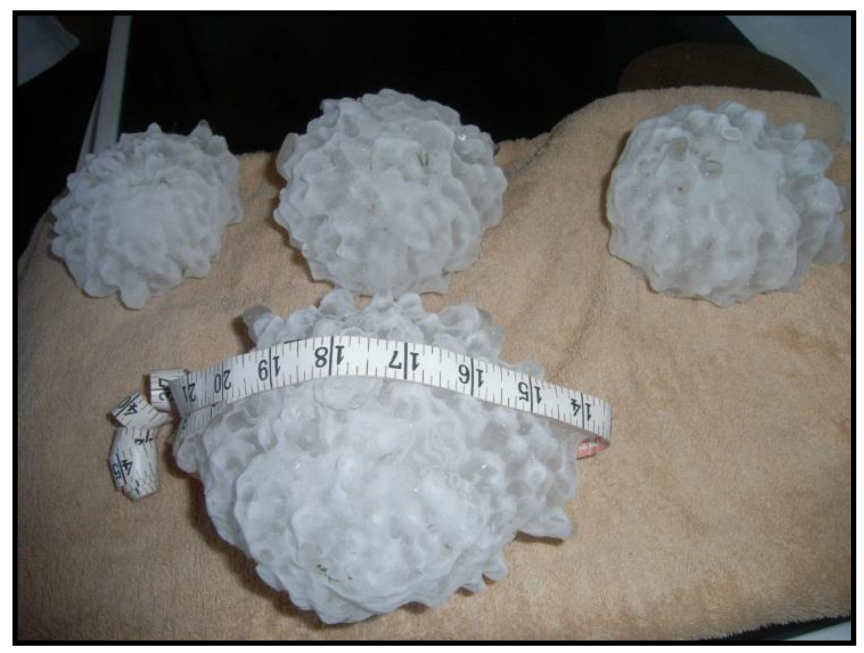

Figure 21. Photograph of the record-setting Vivian hailstone (foreground) along with three other giant hailstones ( $>4$ in diameter) found at the same residence. Click image for larger version.

It is highly likely that melting and/or sublimation of this record hailstone did occur, with contributing factors including exposure to the outdoors and precipitation before retrieval, repeated handling by the resident and onlookers, and the loss of power to the storage freezer before measurements were taken. Though the hailstone was certainly larger when it fell, the official dimensions were those recorded at the time of measurement. Although the hail left divots in the ground, divots were not measured, as their sizes would depend on soil type, moisture, and the hailstone's major axis orientation upon impact. On 28 July 2010, the National Climate Extremes Committee (NCEC) evaluated the validity of the stone and its measurements, and confirmed that the hailstone broke the United States record for maximum diameter and weight (Arndt 2010). Even though the Vivian hailstone was weighed more than 36 hours after the storm, it is remarkable that the weight still broke the previous record. In addition to this record hailstone, there were numerous other hailstones between baseball $(6.99 \mathrm{~cm}$ or $2.75 \mathrm{in})$ and softball size that went completely through vehicle windows (Fig. 23a), roofs (Fig. 23b), garages, and campers. The hail caused five minor injuries to motorists on Interstate 90 as the hailstones broke through their windshields.

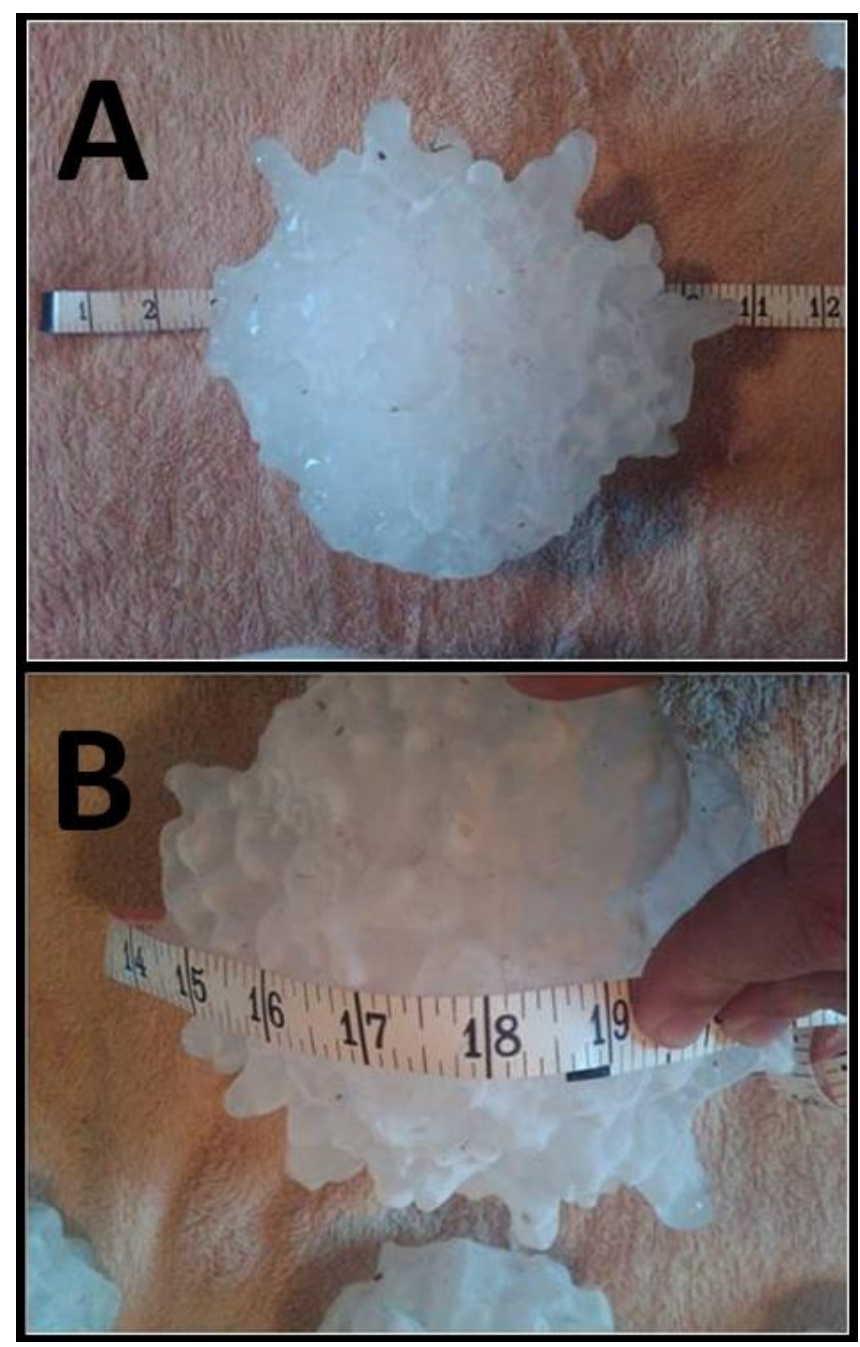

Figure 22. Photographs of the record-setting Vivian hailstone, measuring $20.32 \mathrm{~cm}$ (8.0 in) in diameter (a) and $47.29 \mathrm{~cm}$ (18.62 in) in circumference (b). Click image for larger version.

\section{Discussion and summary}

This case presented several challenges to the meteorologists involved. First, as previously mentioned, the distance from the surrounding radars made it difficult to ascertain storm structures in full detail. Second, the high freezing level height presented forecasters with the notion that hail sizes could be mitigated due to melting aloft. Therefore, forecasters did not discount the threat for hail altogether, but rather thought the melting height could lead to some reduction in hail size. Third, determining that record-breaking hail would occur is never in the forefront of a forecaster's 
mind. Even though the mesoscale environment and expert analysis by SPC indicated a high likelihood for baseball- to softball-size hail, virtually no one would ever predict record hail. Fourth, many of the critical contributors towards hail growth (hail embryo locations, trajectories, microphysics, etc.) were not available to operational forecasters. However, with dual-polarization radar, the enhanced ability to detect these contributors will improve hail forecasting (Kumjian and Ryzhkov 2008; Kumjian et al. 2010). Fifth, verifying a record presents its own challenge: an individual must find the hailstone intact, report it to the NWS, and the NWS must verify the stone within a short period of time. Furthermore, measuring the diameter and circumference of the hailstone can be difficult because of the unique and non-uniform shapes of giant hailstones.

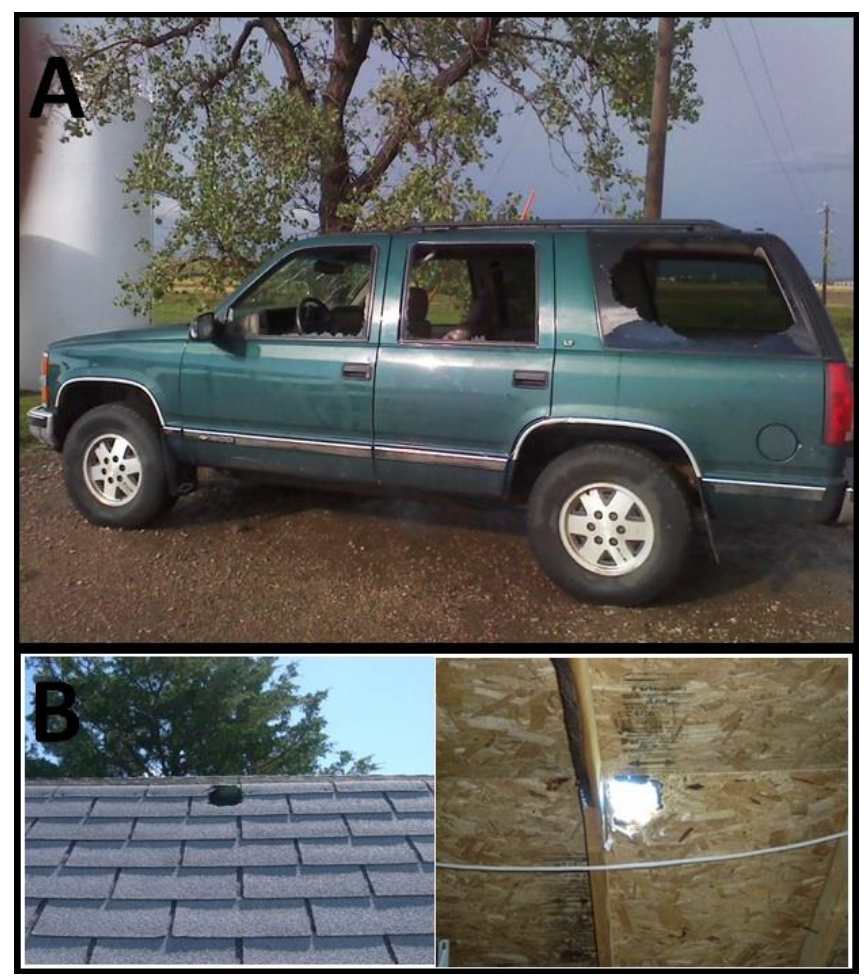

Figure 23. Photographs of vehicle (A) and roof (B) damage from the 23 July 2010 Vivian hailstorm. Click image for larger version.

Although forecasting record-breaking hail is essentially impossible at this time, there were certain environmental and radar characteristics that contributed to the formation of organized severe weather and supercells, including the Vivian hailstone and other giant hailstones, many of which were not unusual for severe thunderstorms in the high plains. The presence of a right entrance region of a strong jet streak, proximity of a shortwave trough, and the warm front over south-central South Dakota, provided for strong upward motion through the depth of the troposphere. Moisture was abundant and flowed into the region via the southerly low-level jet. The CAPE and lapse rates revealed extreme instability from the RUC proximity sounding and SPC mesoscale analyses were also indicative of extreme instability; this included substantial CAPE of $1200 \mathrm{~J} \mathrm{~kg}^{-1}$ in the hail growth zone. Signals of the supercell's severity were apparent, despite the distance from the radars: high reflectivity, intense mid-level rotation, strong STD, an inflow notch, TBSS, and a BWER. Echoes of $65 \mathrm{dBZ}$ up to $12.5 \mathrm{~km}$ $(41,000 \mathrm{ft})$ AGL from KUDX indicated a tall thunderstorm updraft, necessary for the development of large hail. Peak gate-to-gate velocity differences of at least $56 \mathrm{~m} \mathrm{~s}^{-1}(110 \mathrm{kt})$ revealed there was an intense mesocyclone present. Additionally, the fact that the STD of $110 \mathrm{~m} \mathrm{~s}^{-1}(214 \mathrm{kt})$ and a BWER were visible from long distances demonstrated evidence of an exceptionally strong and wide updraft with the ability to produce giant hail. Compared to other giant hail cases (e.g., Blair et al. 2011), the Vivian event showed remarkable values for rotational velocity, STD, maximum 50-dBZ height, and maximum 60-dBZ height. It is hoped by the authors that the material presented herein has demonstrated several key factors that contributed to this record-breaking hailstone, how the Vivian event compares to other giant hail events, and the challenges involved in the forecasting, verification, and post-analysis of this historical occurrence.

Acknowledgements. The authors would like to thank Les Scott for finding the record-breaking hailstone and not making a daiquiri out of it, as he originally contemplated. Dave Hintz, Jim Scarlett, and the NCEC were instrumental in analyzing the hailstone and certifying the record diameter and weight. The involvement of Matt Bunkers (NWS Rapid City) and Phil Schumacher (NWS Sioux Falls) is very much appreciated, as well as the thorough formal evaluations from Les Lemon (NWS WDTB), Scott Blair (NWS Topeka), and Michael Brennan (NHC and 2012 NWA EJOM Editor). Jon Zeitler (NWS Austin/San Antonio), Jeff Craven (NWS Milwaukee/Sullivan), Jeff Manion (CRH), Andrew Detwiler (SDSM\&T), and David Barber (NWS Rapid City) are also thanked for their helpful reviews. The views expressed are those of the authors and do not necessarily represent those of the National Weather Service. 


\section{REFERENCES}

Arndt, D., cited 2010: Official documentation of the verification of the Vivian, SD record setting hailstone of 2010. [Available online at www1.ncdc.noaa.gov/pub/data /cmb/special-reports/ncec/vivian-hailstone-final.pdf.]

Atkins, N. T., M. L. Weisman, and L. J. Wicker, 1999: The influence of preexisting boundaries on supercell evolution. Mon. Wea. Rev., 127, 2910-2927.

Battan, L. J., 1973: Radar Observation of the Atmosphere. University of Chicago Press, $324 \mathrm{pp}$.

Blair, S. F., D. R. Deroche, J. M. Boustead, J. W. Leighton, B. L. Barjenbruch, and W. P. Gargen, 2011: A radarbased assessment of the detectability of giant hail. Electronic J. Severe Storms Meteor., 6 (7), 1-30. [Available online at www.ejssm.org/ojs/index.php/ ejssm/issue/view/32.]

Boustead, J., 2008: Using maximum storm-top divergence and the vertical freezing level to forecast hail size. Preprints, 24th Conference on Severe Local Storms, Savannah, GA, Amer. Meteor. Soc., P6.6. [Available online at ams.confex.com/ams/pdfpapers/142145.pdf.]

Brown, R. A., and K. L. Torgerson, 2005: Interpretation of single-Doppler radar signatures in a V-shaped hailstorm: Part II - Evolution of updraft interactions with ambient mid-altitude flow. Natl. Wea. Dig., 29, 65-80.

Browning, K. A., 1977: The structure and mechanisms of hailstorms. Hail: A Review of Hail Science and Hail Suppression, Meteor. Monogr., No. 38, Amer. Meteor. Soc., 1-43.

Bunkers, M. J., cited 2011: Precipitable water plots. National Weather Service, Rapid City, SD. [Available online at www.crh.noaa.gov/unr/?n=pw.]

Cintineo, J. L., T. M. Smith, V. Lakshmanan, H. E. Brooks, and K. L. Ortega, 2012: An objective high-resolution hail climatology of the contiguous United States. Wea. Forecasting, 27, 1235-1248.

Clark, A. J., C. J. Schaffer, W. A. Gallus Jr., and K. JohnsonO'Mara, 2009: Climatology of storm reports relative to upper-level jet streaks. Wea. Forecasting, 24, 10321051.

Cohen, A. E., 2010: Indices of violent tornado environments. Electronic J. Operational Meteor., 11(6), 1-24. [Available online at www.nwas.org/ej/pdf/2010-EJ6.pdf.]

Donavon, R. A., and K. A. Jungbluth, 2007: Evaluation of a technique for radar identification of large hail across the upper Midwest and central plains of the United States. Wea. Forecasting, 22, 224-254.

Doswell, C. A., III, 1991: A review for forecasters on the application of hodographs to forecasting severe thunderstorms. Natl. Wea. Dig., 16 (1), 2-16. , and D. W. Burgess, 1993: Tornadoes and tornadic storms: A review of conceptual models. The Tornado: Its Structure, Dynamics, Prediction, and Hazards, Geophys. Monogr. No. 79, Amer. Geophys. Union, 161172.
Edwards, R., and R. L. Thompson, 1998: Nationwide comparisons of hail size with WSR-88D vertically integrated liquid water and derived thermodynamic sounding data. Wea. Forecasting, 13, 277-285.

English, M., 1973: Alberta hailstorms. Part II: Growth of large hail in the storm. Alberta Hailstorms, Meteor. Monogr., No. 36, Amer. Meteor. Soc., 37-98.

Foote, G. B., 1984: A study of hail growth utilizing observed storm conditions. J. Climate Appl. Meteor., 23, 84-101.

Guyer, J. L., and R. Ewald, 2004: Record hail event Examination of the Aurora, Nebraska supercell of 22 June 2003. Preprints, 22nd Conf. on Severe Local Storms, Hyannis, MA, Amer. Meteor. Soc., 11B.1. [Available online at ams.confex.com/ams/pdfpapers/ 82087.pdf.]

Hales, J. E., Jr., 1988: Improving the watch/warning program through use of significant event data. Preprints, $15^{\text {th }}$ Conf. on Severe Local Storms, Baltimore, MD, Amer. Meteor. Soc., 165-168.

Howard, K. W., J. J. Gourley, and R. A. Maddox, 1997: Uncertainties in WSR-88D measurements and their impacts on monitoring life cycles. Wea. Forecasting, 12, 166-174.

Johns, R. H., and C. A. Doswell III, 1992: Severe local storms forecasting. Wea. Forecasting, 7, 588-612.

Knight, C. A., and N. C. Knight, 2001: Hailstorms. Severe Convective Storms, Meteorological Monogr., 28, 223248.

Kumjian, M. R., and A. V. Ryzhkov, 2008: Polarimetric signatures in supercell thunderstorms. J. Appl. Meteor. Climatol., 47, 1940-1961.

, J. C. Picca, S. M. Ganson, A. V. Ryzhkov, J. Krause, D. Zrnic, and A. Khain, 2010: Polarimetric radar characteristics of large hail. Preprints, 25th Conf. on Severe Local Storms, Denver, CO, Amer. Meteor. Soc., 1.4. [Available online at ams.confex.com/ams/ pdfpapers/176043.pdf.]

Lemon, L. R., 1980: Severe thunderstorm radar identification techniques and warning criteria. NOAA Tech. Memo., NWS NSSFC-3, 60 pp. [Available from NOAA Central Library, 1315 East-West Highway, Silver Spring, MD 20910.]

, 1998: The radar "three-body scatter spike": an operational large-hail signature. Wea. Forecasting, 13, 327-340.

Maddox, R. A., L. R. Hoxit, and C. F. Chappell, 1980: A study of tornadic thunderstorm interactions with thermal boundaries. Mon. Wea. Rev., 108, 322-336.

, D. S. Zaras, P. L. MacKeen, J. J. Gourley, R. Rabin, and K. W. Howard, 1999: Echo height measurements with the WSR-88D: Use of data from one versus two radars. Wea. Forecasting, 14, 455-460.

Markowski, P. M., E. N. Rasmussen, and J. M. Straka, 1998: The occurrence of tornadoes in supercells interacting with boundaries during VORTEX-95. Wea. Forecasting, 13, 852-859. 
Miller, L. J., J. D. Tuttle, and C. A. Knight, 1988: Airflow and hail growth in a severe northern High Plains supercell. J. Atmos. Sci., 45, 736-762.

Monfredo, W., 2011: Investigation into the record hailstone on 23 July 2010 at Vivian, South Dakota, USA. Weather, 66, 216-221.

Musil, D. J., S. A. Christopher, R. A. Deola, and P. L. Smith, 1991: Some interior observations of southeastern Montana hailstorms. J. Appl. Meteor., 30, 1596-1612.

Rasmussen, E. N., and D. O. Blanchard, 1998: A baseline climatology of sounding-derived supercell and tornado forecast parameters. Wea. Forecasting, 13, 1148-1164.

Rasmussen, R. M., and A. J. Heyms field, 1987: Melting and shedding of graupel hail. Part II: Sensitivity study. J. Atmos. Sci., 44, 2764-2782.

Smith, B. T., R. L. Thompson, J. S. Grams, C. Broyles, and H. E. Brooks, 2012: Convective modes for significant severe thunderstorms in the contiguous United States. Part I: Storm classification and climatology. Wea. Forecasting, 27, 1114-1135.

Thompson, R. L., R. Edwards, and J. A. Hart, 2003: Close proximity soundings within supercell environments obtained from the Rapid Update Cycle. Wea. Forecasting, 18, 1243-1261.

Waldstreicher, J. S., 1989: A guide to utilizing moisture flux convergence as a predictor of convection. Natl. Wea. Dig., 14, 20-35.

WDTB, cited 2012: Beam Property Calculator. Warning Decision Training Branch, Norman, OK. [Available online at: wdtb.noaa.gov/tools/misc/beamwidth/ beamwidth.html.]

Weisman, M. L. and J. B. Klemp, 1984: The structure and classification of numerically simulated convective storms in directionally varying wind shears. Mon. Wea. Rev., 112, 2479-2498. , and _ 1986: Characteristics of is olated convective storms. Mesoscale Meteorology and Forecasting, P. S. Ray, Ed., Amer. Meteor. Soc., 331-358.

Wilson, J. W., and W. E. Schreiber, 1986: Initiation of convective storms at radar-observed boundary-layer convergence lines. Mon. Wea. Rev., 114, 2516-2536.

Witt, A., and S. P. Nelson, 1991: The use of single-Doppler radar for estimated maximum hailstone size. J. Appl. Meteor. 30, 425-431. 